\title{
Therapeutic Potential and Biological Applications of Cordycepin and Metabolic Mechanisms in Cordycepin-Producing Fungi
}

\author{
Peng Qin ${ }^{1}$, XiangKai Li ${ }^{2}{ }^{\circledR}$, Hui Yang ${ }^{1,3}$, Zhi-Ye Wang ${ }^{1,3}$ and DengXue Lu ${ }^{1, *}$ \\ 1 Institute of Biology, Gansu Academy of Sciences, Lanzhou 730000, Gansu, China; \\ kingkerberos@163.com (P.Q.); yanghui43@163.com (H.Y.); Zhiye_wang@sina.com (Z.-Y.W.) \\ 2 Ministry of Education Key Laboratory of Cell Activities and Stress Adaptations, School of Life Sciences, \\ Lanzhou University, Lanzhou 730000, Gansu, China; xkli@lzu.edu.cn \\ 3 Key Laboratory of Microbial Resources Exploition and Application of Gansu Province, Institute of Biology, \\ Gansu Academy of Sciences, Lanzhou 730000, Gansu, China \\ * Correspondence: ludengxue666@163.com; Tel.: +86-931-8418216
}

Received: 5 May 2019; Accepted: 6 June 2019; Published: 14 June 2019

\begin{abstract}
Cordycepin (3'-deoxyadenosine), a cytotoxic nucleoside analogue found in Cordyceps militaris, has attracted much attention due to its therapeutic potential and biological value. Cordycepin interacts with multiple medicinal targets associated with cancer, tumor, inflammation, oxidant, polyadenylation of mRNA, etc. The investigation of the medicinal drug actions supports the discovery of novel targets and the development of new drugs to enhance the therapeutic potency and reduce toxicity. Cordycepin may be of great value owing to its medicinal potential as an external drug, such as in cosmeceutical, traumatic, antalgic and muscle strain applications. In addition, the biological application of cordycepin, for example, as a ligand, has been used to uncover molecular structures. Notably, studies that investigated the metabolic mechanisms of cordycepin-producing fungi have yielded significant information related to the biosynthesis of high levels of cordycepin. Here, we summarized the medicinal targets, biological applications, cytotoxicity, delivery carriers, stability, and pros/cons of cordycepin in clinical applications, as well as described the metabolic mechanisms of cordycepin in cordycepin-producing fungi. We posit that new approaches, including single-cell analysis, have the potential to enhance medicinal potency and unravel all facets of metabolic mechanisms of cordycepin in Cordyceps militaris.
\end{abstract}

Keywords: cordycepin; medicinal targets; biological value; metabolic mechanisms

\section{Introduction}

Cancer, a major threat to public health, is an important cause of death. Recently, the World Health Organization reported that 18.1 million new cases of cancer and 9.6 million cancer deaths occurred in 2018 [1]. In China, cancer has been the leading cause of death since 2010 [2]. Notably, cordycepin (3'-deoxyadenosine [3], COR), discovered in the broth of Cordyceps militaris [4], has received a large amount of attention due to its enormous therapeutic potential, as well as its effects on intracellular signal transduction and cell adhesion [5]. COR interferes with many pathological processes via the inhibition of mRNA polyadenylation $[6,7]$ and the regulation of a variety of targets involved in various cellular processes, such as anticancer(apoptosis and autophagy induction, leukemic stem cell (LSC) elimination, cell cycle arrest, and antimetastatic, anti-invasion, and antiproliferation activities), anti-inflammatory, antioxidant, antipathogenic, insecticidal, antihyperlipidemic, antihepatotoxic, antifibrotic and neuroprotective activities, skin photoaging protection, skeletal muscle fatigue repression, protection from ischemia/reperfusion-induced injury and bone protection (Figures 1-4). 
Several potential reasons may account for the multiple bioactivities of COR: (i) Cordycepin triphosphate (COR-TP) may be initially generated through the phosphorylation of COR [8], which is incorrectly recognized as ATP binding to targeted enzymes and replaces ATP due to the highly structural similarity between COR-TP and ATP. Enzymes also erroneously recognize COR as adenosine, which causes abnormal purine metabolism. (ii) COR and/or COR-TP inhibit targets by replacing ATP binding to targeted protein kinases with the highly structural similar COR-TP [9] and/or the activation of protein phosphatases [10]. (iii) COR and/or COR-TP directly activate protein kinases, such as AMPK [11] potentially because of an increase in the AMP/ATP ratio. (iv) COR and/or COR-TP interrupt mRNA polyadenylation because of the erroneous recognition of COR-TP as ATP by PolyA polymerase [7]. In addition, COR has the potential to act as a ligand [12] and a RNA elongation inhibitor [13], and it can specifically inhibit transcription efficiency [14].

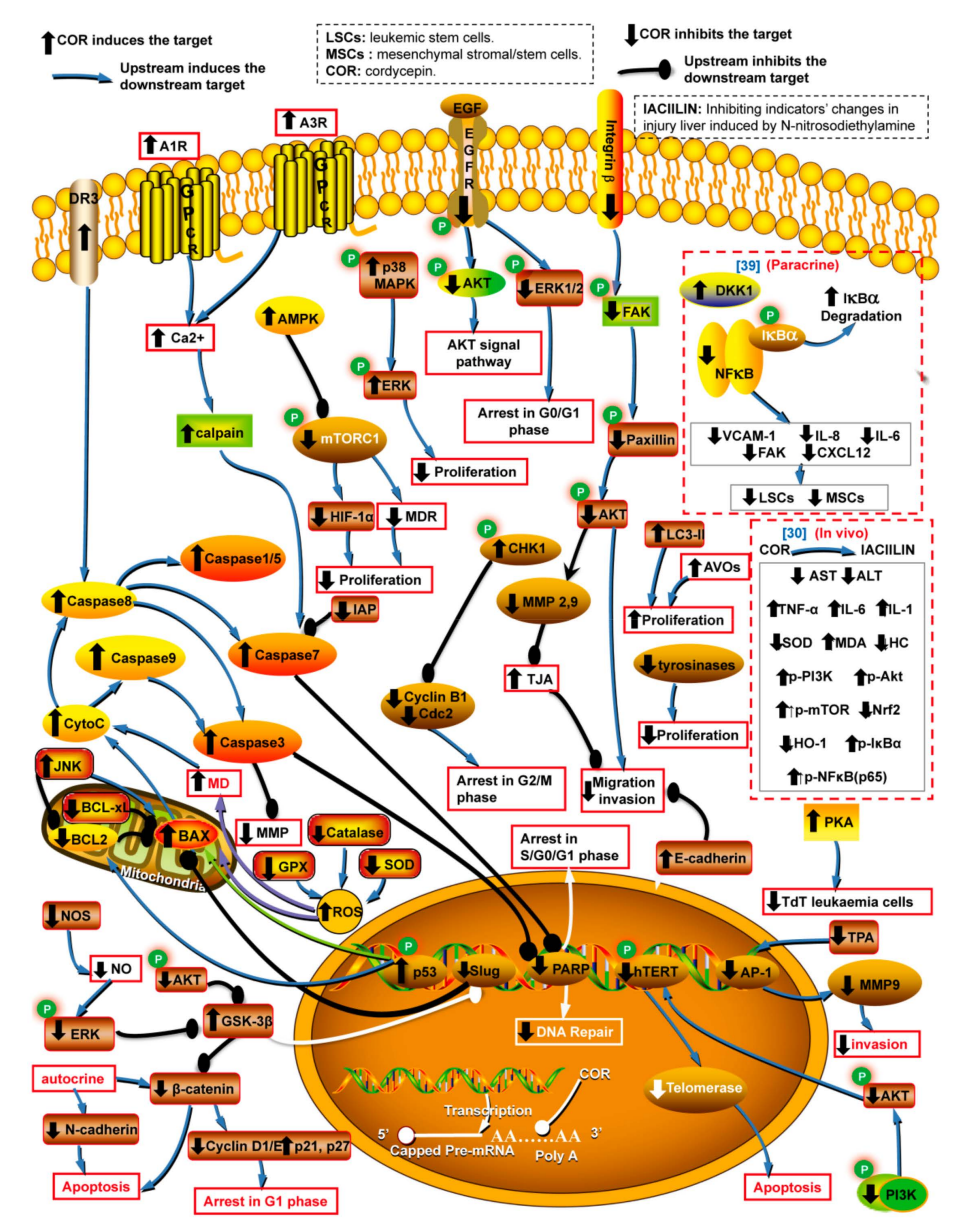

Figure 1. Cellular targets of cancer affected by cordycepin via various signal pathways. Note: A1R: adenosine A1 receptor. A3R: adenosine A3 receptor. GPCR: G protein-coupled receptor. TJA: tight junction activity. IL: interleukin. SOD: Superoxide Dismutase. NOS:nitric oxide synthase. CHK1: Checkpoint kinase 1. GPX: Glutathione peroxidase. EGFR: epidermal growth factor receptor. AVOs: acidic vesicular organelles. P-: phosphorylated. MMPs: matrix metalloproteinases, such as MMP-2 and MMP-9. AP-1 and NF-kB: transcription factors that bind to the promoter of MMP-9 gene and play an important role in regulating MMP-9 [15]. LC3-II: an autophagosome marker, and the cytoplasmic form LC3-I (18 kDa) is converted to LC3-II during autophagy [16]. DR3: death receptor3. TPA: 12-O-tetradecanoylpho-bol-13-acetate. PARP: Poly (adenosine-diphosphate-ribose) polymerase. HC: histopathology condition. HIF- $1 \alpha$ : hypoxia-inducible factor $1 \alpha$. MDR: multiple drug resistant. AMPK: adenosine 5'-monophosphate-activated protein kinase. MD: mitochondrial disfunction. The blue numbers in square brackets represent references associated with in vivo results. These abbreviations are also used in this paper. 


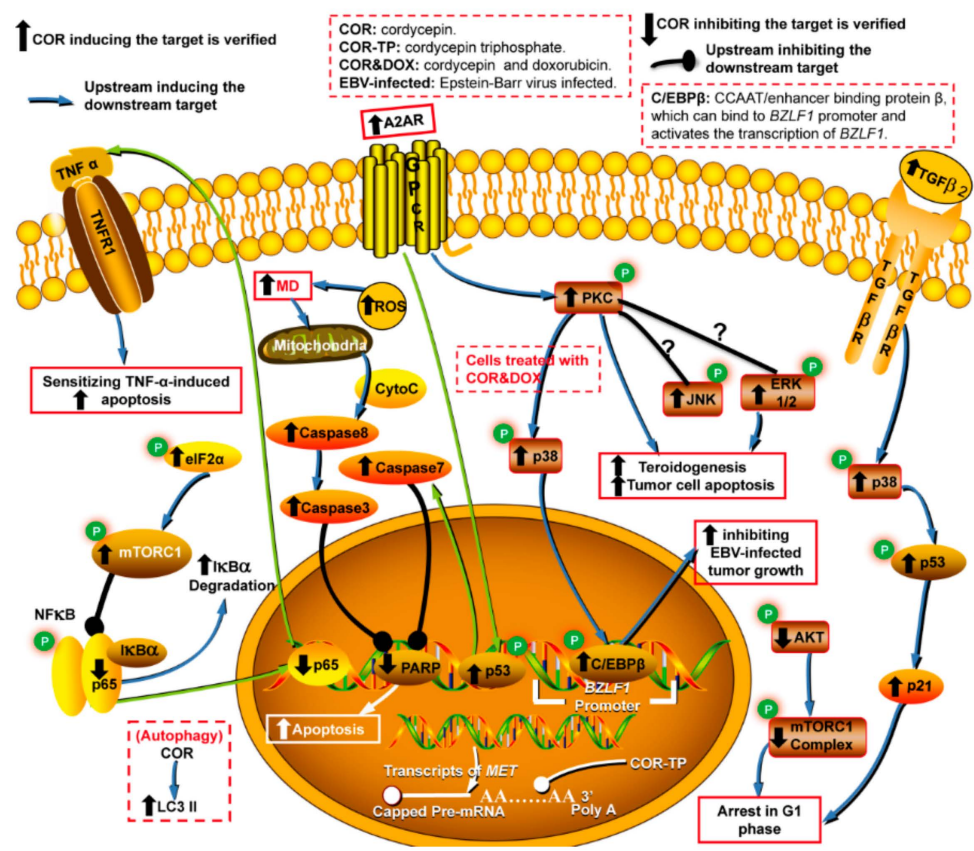

Figure 2. Cellular targets of tumor affected by cordycepin via various signal pathways. Note: ROS: reactive oxygen species. C/EBP $\beta$ : CCAAT/enhancer binding protein $\beta$, which can bind to BZLF1 promoter and activate the transcription of BZLF1 [17]. MD: mitochondrial disfunction. These abbreviations are also used in this paper.

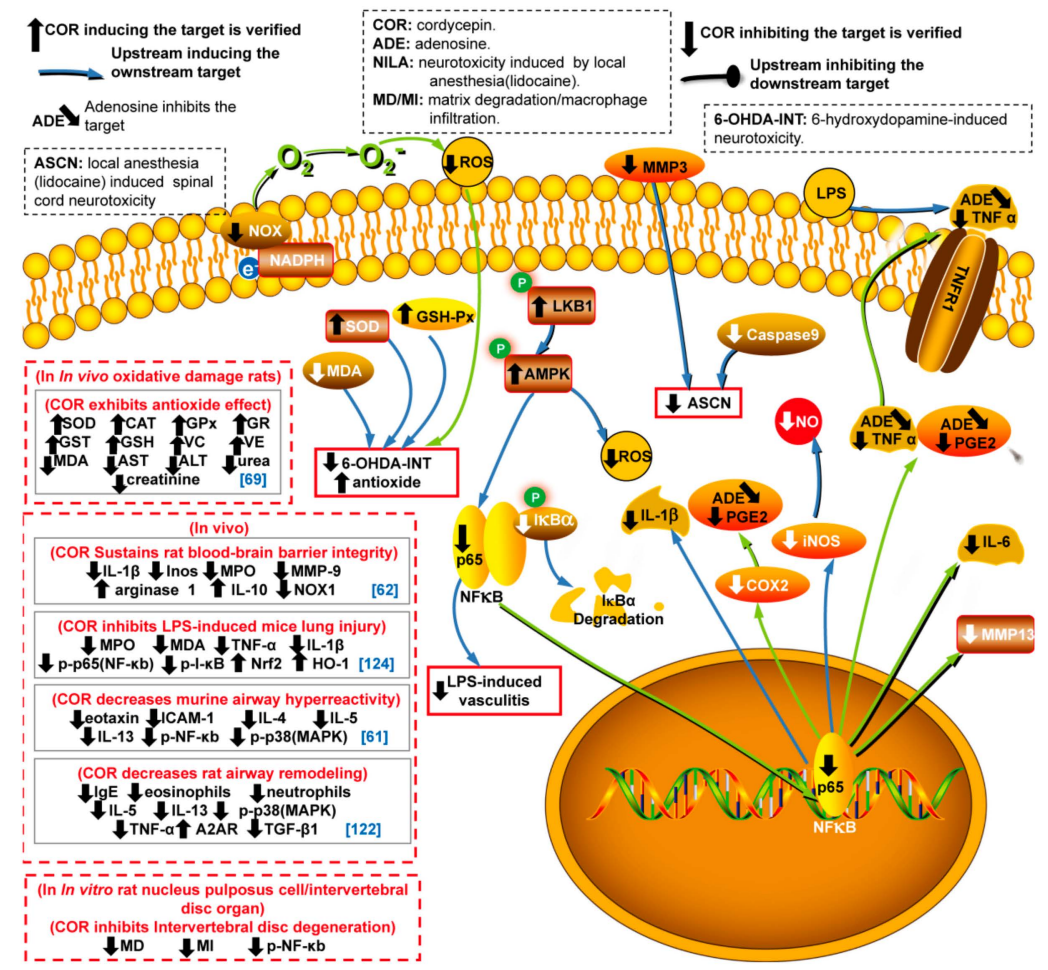

Figure 3. Anti-inflammatory and anti-oxidant targets affected by cordycepin via various signal pathways. Note: SOD: superoxide dismutase. GSH-Px: glutathione peroxidase. MDA: malondialdehyde. 6-OHDA-INT:6-hydroxydopamine-induced neurotoxicity. VC: Vitamin C. VE: Vitamin E. IL-1 $\beta$ : interleukin-1 beta. iNOS: inducible nitric oxide synthase. PGE2: prostaglandin E2. NO: nitric oxide. COX-2: cyclo-oxygenase. NF-kB: nuclear factor kappa-B. iNOS: inducible nitric oxide synthase. IgE: immunoglobulin E. ICAM-1: intercellular cell adhesion molecule-1. HO-1: heme oxygenase-1. These abbreviations are also used in this paper. 


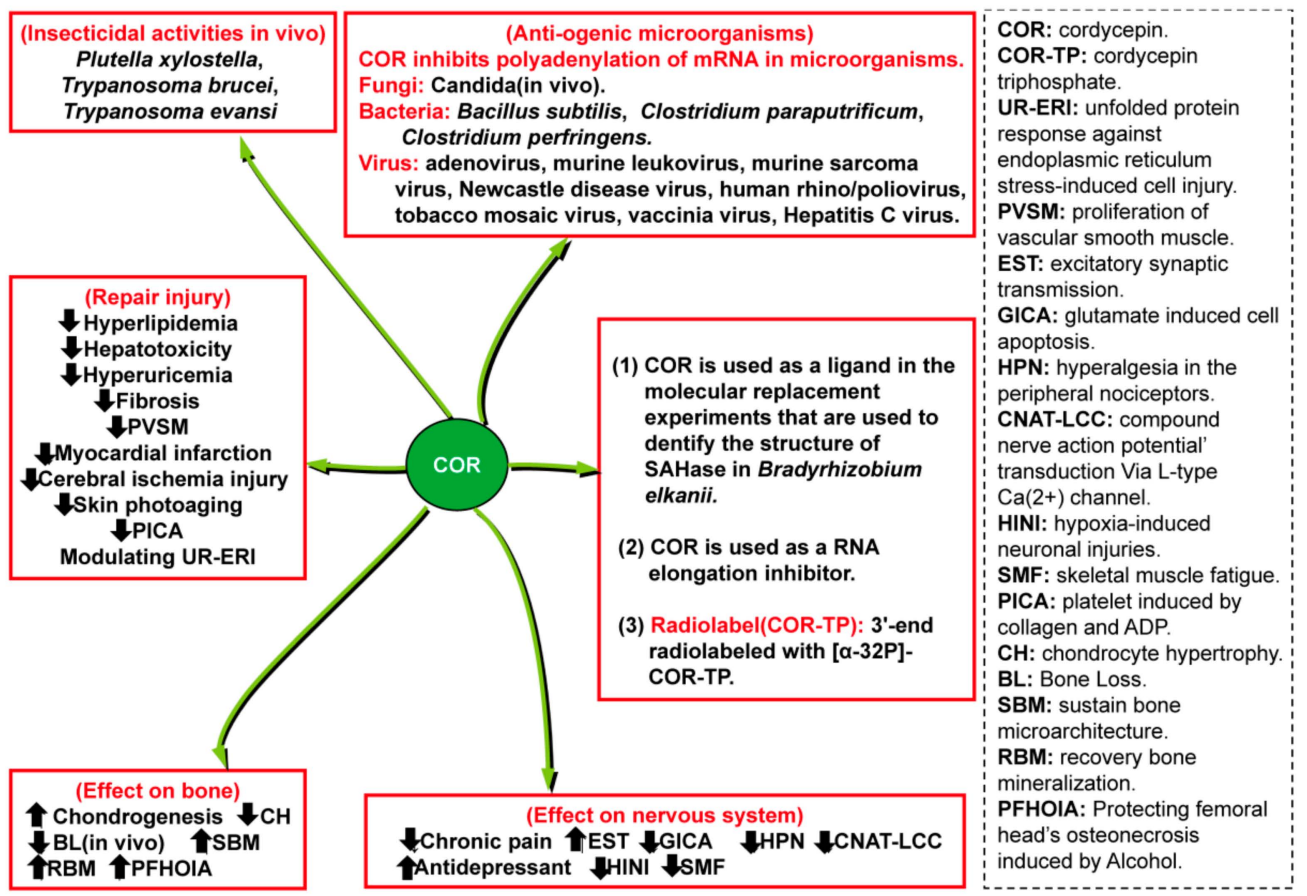

Figure 4. Other medicinal value and biological applications. Note: COR can also inhibit excitatory synaptic transmission [18] and have neuroprotective effects [19]. ER-COR has antiplatelet effects [20]. The $[\alpha-32 \mathrm{P}]-\mathrm{COR}-\mathrm{TP}$ is used for $3^{\prime}$-end radiolabeled RNA fragments [21].

However, the large-scale production of COR is a significant challenge. Hence, COR serves as an important marker for the quality control of $C$. militaris. The COR content of $C$. militaris is significantly higher than that of other currently known fungi. The maximum production of COR obtained in liquid-cultured C. militaris by mutant G81-3 and in the fruiting body of wild C. militaris reached $14.3 \mathrm{~g} / \mathrm{L}$ [22] and $9.45 \mathrm{mg} / \mathrm{g}$ [23], respectively. For the same C. militaris, the COR content in the fruiting body was significantly higher than that in the mycelia [24]. Notably, the COR biosynthetic mechanism in C. militaris was completely elucidated [24] through a comparative analysis of the conserved genes of two phylogenetically distant and COR-producing species, Aspergillus nidulans [25] and C. militaris. Intriguingly, pentostatin (PTN), which protects COR from deamination by adenosine deaminase (ADA), was first discovered in the fruiting body of C. militaris (FB-CM) rather than in the mycelia [24].

Although the medicinal potential of COR [26-28], the COR analogs in mushrooms [29] and the pharmacological effect of COR on male reproduction [30] have been extensively reviewed, little attention has been paid to the medicinal targets, cytotoxicity, delivery carriers, stability, and biological applications of COR, the metabolic mechanisms in COR-producing fungi, and the pros/cons of COR in clinical applications, and the clinical potential of the external use of COR. In fact, these aspects are thought to be significant issues for the medicinal applications of COR. In addition, the mechanisms of disease treatments with chemotherapeutic agents, such as COR, are sophisticated. It is essential to improve the efficiency of chemotherapeutics agents, to design analogs suitable for clinical treatment, and to develop novel therapeutic strategies via in-depth understanding of COR. Therefore, this review briefly summarizes these aspects. In addition, we discuss new approaches that will greatly contribute to uncovering the metabolic mechanisms of all facets of COR in C. militaris.

\section{Anticancer Activity in Similar Signaling Pathways}

\subsection{Induction of Apoptosis and Promotion of Autophagy}

Apoptosis, a type of programmed cell death (type I cell death), is characterized by marked changes inmorphology and other biochemical markers, that involves the activation of caspases via extrinsic (cell 
membrane receptors), intrinsic mitochondrial-related and endoplasmic reticulum (ER) stress-related pathways. COR suppresses the growth of cancer cells by blocking formation of the polyA tail on mRNA at the transcriptional level and affects various targets in different signaling pathways [7] (Figure 1 and Table S1). Studies have shown that COR induces the apoptosis of cancer cells via cell membrane receptors [31], mitochondria [32] and PI3K/Akt [33] signal pathways. Mechanistically, COR not only activates death receptor 3(DR3) [34], adenosine G protein-coupled receptors (GPCRs) [31], tumor suppressor p53 [35] and pro-apoptotic proteins (Bax and caspases) [32] but also inhibits anti-apoptotic proteins (BCL-2 and BCL-xL) [36] and PI3K/Akt [33].

COR induces the apoptosis of cancer cells via extrinsic pathways, including the activation of DR3/caspase-8/caspase-1 pathway in the in vitro colonic cancer cell line HT-29 [34] and the stimulation of adenosine A1 receptor (A1R)/adenosine A3 receptor (A3R)/intracellular calcium (IC)/calpain/caspase7/poly adenosine-diphosphate-ribose polymerase (PARP) pathway in the in vitro thyroid cancer cell line CGTH W-2 [31], and by increasing the level of tumor necrosis factor- $\alpha$ (TNF- $\alpha)$ bound to tumor necrosis factor receptor (TNFR) in hepatocellular cancermice in vivo [37]. Notably, COR stimulates $A 1 R$ and $A 3 R$ to a greater extent than it stimulates the adenosine $A 2 A$ receptor $\left(A_{2 A} R\right)$ and adenosine $\mathrm{A} 2 \mathrm{~B}$ receptor $\left(\mathrm{A}_{2 \mathrm{~B}} \mathrm{R}\right)$ [31].

In addition, COR stimulates apoptosis of cancer cells through intrinsic pathways, such as mitochondrial, PI3K/Akt and autophagy pathways. For the mitochondrial pathway, COR not only affects the proapoptotic/anti-apoptotic proteins in mitochondria but also causes mitochondrial dysfunction. Previous work reported that COR induces the apoptosis of breast cancer cells in vitro via the Bax/cytochrome $\mathrm{c}$ (cyt c)/caspases-9/caspases-3/PARP pathway in the MDA-MB-231 cell line [32]. Notably, COR stimulates mitochondrial dysfunction by modulating the intracellular level of gaseous signaling molecules, such as increasing reactive oxygen species (ROS) and decreasing nitric oxide(NO). Mitochondrial dysfunction induces the release of Bax and Cyt c from the mitochondria to the cytoplasm and activates a downstream pathway that includes caspases. Previous studies demonstrated that COR induces the apoptosis of cancer cells by enhancing intracellular ROS via the ROS/caspase-8/caspase-9/caspase-3/caspase-5/caspase-7 pathway in human leukemia cell lines (U937 and THP-1) in vitro [38] and via an antioxidant protein-mediated pathway (GPX/superoxide dismutase (SOD)/Catalase/ROS/Bax/BCL-2/caspase-9/caspase-3) in brain cancer cell lines (SH-SY5Y and U-251) in vitro [36]. Nevertheless, COR decreases ROS levels in the mononuclear cells of peripheral blood samples from both healthy subjects and subjects with Kawasaki disease [39]. This finding suggests that COR exhibits contrasting effects under different conditions. In addition, COR induced apoptosis in vitro in the human lung cancer cell line A549 by inhibiting the intracellular NO via the nitric oxide synthase (NOS)/NO/EKR/GSK-3ß/Slug/Bax/caspase-3/PARP pathway [40]. Furthermore, COR stimulates apoptosis by inhibiting the PI3K/Akt pathway (PI3K/Akt/hTERT/telomerase) inleukemia cell line (U937 and THP-1) in vitro [33] and induces autophagy (type II cell death) in the breast cancer cell line MCF-7 in vitro [32].

\subsection{Cell Cycle Arrest}

The cell cycle is regulated by cyclins, cyclin-dependent kinases (CDKs) and cyclin-dependent kinase inhibitors (CDKIs). The complex of a cyclin and the corresponding CDK, which is inhibited by CDKIs, arrests the cell cycle. Previous research demonstrated that COR promotes cancer cell cycle arrest at certain cell cycle phases by inhibiting cyclins (cyclins D1 [41,42], E [42] and B1 [43]), repressing CDKs(cdc2) [43] and inducing CDKIs (p21 and p27) [42] (Figure 1 and Table S1). Additionally, previous work demonstrated that COR arrests the cancer cell cycle at the G1 phase in vitro via the PI3K/Akt pathway (Akt/GSK-3b/ $\beta$-catenin/cyclinD1) in the leukemia cell line U937 [41] and the CDKIs (p21/p27)/Cyclin(D1 and E) pathway in the leukemia cell line BCRC60176 [42]. In addition, COR promotes cancer cycle arrest at the G2/M phase via the checkpoint kinase 1 (CHK1)/cylinB1-cdc2 complex pathway in the cervical cancer cell line (HeLa) in vitro [43]. Notably, COR induces cell cycle arrest at the G0/G1 phase in in vitro lung cancer cell line H1975 via decreasing the level of phosphorylated 
epidermal growth factor receptor (EGFR), subsequently causing a decrease in phosphorylated AKT and phosphorylated ERK1/2. COR binds to the tyrosine kinase domain of EGFR and interferes with ATP binding to prevent EGFR phosphorylation [9]. Therefore, COR and its derivatives, as novel EGFR inhibitors, have the potential for further medicinal applications.

\subsection{Suppression of Metastasis, Invasion, Proliferation and Mesenchymal Stem Cells}

Cancer, a type of malignant tumor, is formed from benign tumors through a series of processes that involve embryonic cells, mesenchymal stem cells, fibroblasts, fibrocytes and malignant tumor cells. In contrast to benign tumors, cancer is characterized by rapid progression, including metastasis, invasion and proliferation. The malignant properties of tumors are not only controlled by cancer cells but also driven by microenvironment of the tumor cells [44], including a variety of nonmalignant cells (macrophages, fibroblasts, inflammatory cells and mesenchymal stem cells) [44], the paracrine signaling exchange of cytokines [45], cell adhesion factors ( $\beta$-catenin and N-cadherin) [46], growth factors [45], tumor cell release factors [47] and transforming growth factor-beta (TGF- $\beta$ ) [48].

As shown in Figure 1 and Table S1, Previous studies demonstrated that COR represses the metastasis of glioblastoma cancer cells via the inhibition of the integrin $\beta 1$ receptor pathway (integrin $\beta 1$ receptor/FAK/paxillin/Akt) by lysosomal degradation in in vitro cell lines (ANM, U87MG and LN229) in vitro [10]. Noteworthily, COR can activate protein phosphatases to inhibit targets (integrin $\beta 1$ receptor, FAK, paxillin and Akt) [10]. In addition, COR inhibits migration and invasion via MMP-mediated pathways in vitro, for example, COR suppressed the AKT pathway (AKT/MMP-9/MMP-2) in the prostate cancer cell line LNCaP [49], repression of MMP-9/MMP-2 in in vitro lung cancer cell line CL1-0 [50] and inhibited the AP-1 pathway (TPA/AP-1/MMP-9) in the breast cancer cell line MCF-7 [51]. In addition, COR has been demonstrated to repress epithelial-mesenchymal transition via the upregulation of E-cadherin and downregulation of $\mathrm{N}$-cadherinin in vivo oral cancer-bearing mice [52].

In addition, as shown in Figure 1 and Table S1, COR inhibits proliferation by activating the adenosine 5'-mono-phosphate-activated protein kinase (AMPK) pathway (AMPK/mTORC1/MDR $/ \mathrm{HIF}-1 \alpha)$ in vitro in the gallbladder cancer cell line GBC-SD [11], by inducing the p38 MAPK pathway (p38 MAPK/ERK) in vitro in the renal cancer cell line 786-O [53], and by inactivating tyrosinases in vitro in the lung cancer cell lines (A549 and Caalu-3) [54]. Notably, AMPK is generally activated in response to a high adenosine $5^{\prime}$-monophosphate AMP/ATP ratio [55]. It is speculated that COR may cause an increase in the AMP/ATP ratio, which induces AMPK. The speculation requires further investigation. Moreover, COR inhibits the progression of leukemia by inhibiting leukemic stem cells (LSCs) and suppressing leukemia-stromal interactions (LSIs). Both LSCs and LSIs can develop resistance to chemotherapeutics. Mechanistically, COR induces apoptosis of leukemia cells via the autocrine signaling pathway in in vitro cell lines (U937/K562) by decreasing cell adhesion factors ( $\beta$-catenin and $\mathrm{N}$-cadherin) and via the paracrine signaling pathway in vivo in the U937/K562-inoculated mice by inducing Dickkopf-1 (DKK1, a wnt/ $\beta$-catenin inhibitor [56]), and restraining the NFkB pathway [46]. The anticancer properties of COR in other in vivo studies are shown in Figure 1/Table S1 and are labelled in the square brackets using the blue numbers associated with the corresponding references.

\section{Antitumor Activity}

\subsection{Apoptosis Inhibition, mTOR Repression and Cell Cycle Arrest}

The inhibition effect of COR on benign tumor cells is less pronounced than that on highly aggressive cancer cells [57]. COR does not impact healthy and noncancerous cells [54]. COR induces apoptosis of tumor cells through mitochondria (caspases) and the mTOR and autophagy pathways, as well as by inhibiting ER stress-induced injury (Figure 2 and Table S2). COR promotes the apoptosis of tumor cells through various pathways in vitro, for example, COR represses the transcription of MET in the multiple myeloma cell line MM.1S [58], activates the ROS-mediated mitochondria 
pathway (ROS/caspase-8/caspase-3/PARP) and induces autophagy in the Leydig tumor cell line MA-10 in a dose-dependent manner [59] and stimulates p53 signaling $\left(\mathrm{A}_{2 \mathrm{~A}} \mathrm{R} / \mathrm{p} 53 /\right.$ caspase-7/PARP $)$ in the glioma cell line C6 (malignant tumor cell) [60]. In addition, COR can bidirectionally regulate mTOR signaling under different conditions. The literature indicates that COR represses tumor growth in vitro by inhibiting mTOR pathway (AKT/mTOR) in the Leydig tumor cell line MA-10 [59]; however, in the healthy renal cell line NRK-52E and in other cell types, COR induces the mTORC1 pathway (elF2 $\alpha /$ mTORC1/p65 of NF-KB), which then sensitizes cells to TNF- $\alpha$-induced apoptosis [61]. Similar to previous work [61], COR was found to suppress ER stress-induced apoptosis in vitro in the NRK-52E cell line [62]. In other words, COR kills TNF- $\alpha$-treated NRK-52E cells and has a protective effect on NRK-52E cells against ER stress-induced apoptosis, suggesting that COR bidirectionally regulates apoptosis. In addition, COR promotes the cell arrest of tumor cells at the G2/M phase in vitro by inducing TGF 32 -mediated extrinsic pathway (TGF $32 / \mathrm{p} 38 / \mathrm{p} 53 / \mathrm{p} 21$ ) in the Leydig tumor cell line MA-10 [59].

\subsection{Suppression of Tumor Growth via the GPCR/PKC Signaling Pathway}

MAPK cascades are important stress-responsive signaling pathways that govern a wide variety of functions implicated in tumor growth. MAPK signaling pathways consist of three components: MAPKs, MAPK kinases and MAPK kinase kinases. GPCRs, including adenosine receptors, can activate the MAPK pathway [63]. Phospholipase C (PLC) is induced by GPCR and stimulates protein kinase C (PKC) to activate the downstream event. COR inhibits tumor cell growth through MAPK pathways (Figure 2 and Table S2). COR significantly promotes steroidogenesis via the PKC/JNK/ERK1/2 pathway rather than via the PKA/PI3K/p38 MAPK pathway in vitro in the Leydig tumor cell line MA-10 [64]. In addition, COR inhibits tumor growth via the PKC/p38 MAPK/transcription factor (C/EBP $\beta$ ) pathway in vivo in Epstein-Barr virus-infected mice [17].

\section{Anti-Inflammatory and Anti-Oxidant Activities in Different Cell Lines}

\subsection{Anti-Inflammatory Activity}

COR has been demonstrated to exhibit anti-inflammatory activity in different cell lines $[39,65,66]$. Mechanistically, this effect is ascribed to the protection of IKB- $\alpha$ from degradation, which inhibits NF- $\mathrm{KB}$, and to the inactivation of MAPK [67]. The effect of COR on NF- $\mathrm{KB}$, AMPK and MAPK directly or indirectly cause the downregulation of proinflammatory and inflammatory factors (PGE2 $[65,66]$, COX-2 [65,66], Inos [66], IL-1 $\beta[65,66]$, and TNF- $\alpha$ [65]) and the upregulation of anti-inflammatory factors (interleukin proteins) [68] (Figure 3 and Table S3). COR exhibits anti-inflammatory properties via various signaling pathways in vitro in different cell lines. In RAW 264.7 cell lines, COR inhibits inflammation in vitro via the activation of the LKB1 pathway (LKB1/AMPK/NF-KB and ROS) during the treatment of Kawasaki disease [39] and represses lipopolysaccharide (LPS)-induced inflammation by inhibiting TNF- $\alpha$ and PGE2 [65]. In IL-1 $\beta$-induced human osteoarthritis chondrocytes in vitro, COR exhibits anti-inflammatory effect via the inhibition of the p65 NF- $\mathrm{kB}$ pathway (IKB- $\alpha / \mathrm{p} 65$ NF-kB/COX-2/PGE2/iNOS/NO/MMP-13 /IL-6) [66]. Moreover, the anti-inflammatory properties of COR have been observed in the HMC-1 cell line, where COR inhibits inflammatory factors (IL-13/IL-6/TNF- $\alpha / \mathrm{IL}-1 \beta$ ) in atopic dermatitis treatment [69], and in vitro in rat spinal cord dorsal root ganglia neurons, where COR inhibits caspase-9 and MMP-9 in local anesthesia-induced spinal cord neurotoxicity [70].

\subsection{Anti-Oxidant Activity}

Endogenous enzymes that scavenge free radical and act as antioxidants become dysfunctional with age, which causes the aberrant accumulation of ROS. Previous work demonstrated that the anti-oxidant activity of COR and adenosine from water extracts of C. militaris is limited [71,72]. Mechanistically, as shown in Figure 3 and Table S3, COR exhibits anti-oxidant activity via a decrease in intracellular 
ROS by regulating antioxidant and oxidant enzymes and antioxidants, including decreasing the level of NADPH oxidase in vitro in the tubulointerstitial fibrosiscell line HK2 [73], decreasing the level of malondialdehyde (MDA) and activating SOD and glutathione peroxidase (GSH-Px) to protect cell line PC12 against 6-hydroxydopamine-induced neurotoxicity in in vitro studies of Parkinson's disease [74]. In addition, COR decreases ROS in vivo in radical-induced oxidative damaged rats [75].

The anti-inflammatory and anti-oxidant properties of COR in other in vitro and in vivo studies are shown in Figure 3 and Table S3.

\section{Other Medicinal Values and Biological Applications}

\subsection{Insecticidal Activity and Inhibition of the Growth of Pathogenic Microorganisms}

COR, which is very similar to adenosine but lacks a $3^{\prime}$-hydroxyl group, can be erroneously identified and replaces nucleosides and interrupts the polyadenylation of mRNA, causing dysfunction and inhibiting the growth of pests and pathogenic microorganisms (Figure 4 and Table S4). Previous work demonstrated that COR inhibited the growth of pathogenic microorganisms, including Bacillus subtilis [76], adenovirus [77,78], murine leukovirus [79], murine sarcoma virus [80], Newcastle disease virus [81], human poliovirus [82], tobacco mosaic virus [83], vaccinia virus [84], hepatitis C virus [85], Clostridium paraputrificum and Clostridium perfringens [86] and Candida [87]. The effect of COR on human immunodeficiency virus (HIV) is not well understood, and additional investigations are needed to tackle this issue. Notably, the efficacy of a mosaic adenovirus serotype 26-based HIV-1 vaccine that exhibits excellent immune responses, safety and tolerability in humans and rhesus monkeys are being evaluated in phase $2 \mathrm{~b}$ clinical trials in sub-Saharan Africa [88].

In addition, COR exhibits insecticidal effects (Figure 4 and Table S5). COR can induce cell death in pests, including Plutella xylostella [89], Trypanosoma brucei [90] and Trypanosoma evansi [91]. The combination of COR $(2 \mathrm{mg} / \mathrm{kg})$ and PTN $(0.2 \mathrm{mg} / \mathrm{kg})$ has significant therapeutic potency and decreases toxicity in T. evansi-infected mice [92]. Notably, COR induces programmed cell death rather than repression of chitin synthesis in vivo in larvicidal P. xylostella [89]. In addition, COR exhibits antifungal activity, such as against different Candida isolates [87]. Considering that chitin is the major component of the fungal cell wall, a combination of COR and chitin synthase inhibitors is a promising strategy in insecticidal and antifungal applications.

\subsection{Inhibition of External Factor-Induced Injury}

External factors often result in a series of secondary pathological effects and/or alter the function of healthy tissues and organs, causing longterm disability or death. Studies have revealed that COR enhances injury repair via several pathways $[93,94]$.

Skin aging is a degenerative physiological process induced by both internal and external factors [93]. Previous work demonstrated that COR suppresses skin photoaging [95], inhibits fibrosis and exhibits antioxidant properties [94] (Figure 4 and Table S5). In previous skin photoaging studies, COR represses skin photoaging in vitro by blocking UVB-induced NF- $\mathrm{kB}$ activation, and the NF- $\mathrm{kB}$ inactivation subsequently downregulates $M M P-1$ and $M M P-3$ expressions. The inhibition of $M M P$ is a promising strategy in skin cancer and photoaging therapy [95]. Moreover, COR represses lung fibrosis by increasing E-cadherin expression and decreasing vimentin levels [96] and inhibits kidney fibrosis by inactivating targets (CAGA box, BRE and Smad1/2/3) and stimulating eIF2 $\alpha$ [97]. In addition, COR plays a significant role in suppressing atopic dermatitis [69]. Therefore, COR has cosmeceutical potential with additional medicinal applications.

Trauma induces many physiological changes that subsequently cause complications, such as ischemia injury. As shown in Figure 4 and Table S5, previous work indicated that COR inhibits ischemic injury in vivo in myocardial infarction [98] and cerebral ischemia injury [99]. Notably, remote ischemic preconditioning can also protect target tissues/organs from injury and has notable developmental potential because of its clinical safety, simplicity, and acceptance. Pre-treating target tissues/organs 
with COR coupled with remote ischemic preconditioning is considered to be an efficient and promising strategy to overcome ischemic injury. In addition, trauma may also cause physiological complications, including pathogenic microorganism infection, physiological changes in local blood vessels, and provisional or chronic pain. COR can markedly inhibit growth of specific pathogenic microorganisms, restrain these physiological changes and repress neuropathic pain due to its multiple bioactivities. COR suppresses the proliferation of vascular smooth muscle exclusively [100]. In addition, COR can markedly suppress hyperactivity of nerve tissue by interrupting the L-type $\mathrm{Ca}^{2+}$ channel-mediated transduction of compound nerve action [101], blunting the peripheral nociceptors [102] and significantly suppress chronic pain by decreasing the level of PEG2 [103]. In addition, COR markedly decreases skeletal muscle fatigue-induced muscle strain [104]. These results suggest that COR has the potential to be used as an external drug for trauma and muscle strain as well as for remote ischemic preconditioning.

\subsection{Inhibition of Internal Factor-Induced Injury}

Compared with external factors, internal factors, which include ER stress, over-adipogenesis in tissues/organs, alcohol-induced dysfunction of tissues/organs and neurological disorders, may cause several serious pathological changes, such as ER stress-induced injury, hepatotoxicity and neurodegeneration. As shown in Figure 4 and Table S5, COR protects against ER stress-induced injury by inducing eIF2 $\alpha$ and inhibiting GADD34 [62]. In addition, COR suppresses adipogenesis-induced and alcohol-induced hepatotoxicity $[105,106]$, inhibits hyperlipidemia by activating AMPK $[107,108]$ and inhibits depression by promoting GluR1 expression [109].

\subsection{Promotion of Chondrogenesis and Inhibition of Bone Loss}

Currently, osteoporosis represents a marked public health challenge. Previous work revealed that COR protects against osteoporosis as a result of increased bone generation and inhibited bone loss (Figure 4 and Table S5). Mechanistically, COR alleviates osteonecrosis via a decrease in ROS [110], protects the femoral head from alcohol-induced injury by activating $\beta$-catenin and Runx2 [111] and induces chondrogenesis through the stimulation of PI3K and MMP-13 [112].

\subsection{Biological Applications of COR and COR-TP}

COR structurally resembles adenosine, except that COR lacks a $3^{\prime}$ hydroxyl group, which significantly enhances the ability of COR to form transition metal complexes in the form of di-, triand tetra-dentate ligands [12]. COR and COR-TP have many biological applications (Figure 4 and Table S5). COR has been used as a ligand in molecular replacement experiments that are used to identify the molecular structure of SAHase in Bradyrhizobium elkanii [113]. Furthermore, since COR inhibits the PolyA formation of mRNA, the presence of COR can cause premature transcription termination. Previous research used COR as an RNA elongation inhibitor, and bromine in BrUTP was used to elucidate the structure of active rRNA gene in the nucleolus. Pretreated with COR, premature rRNA elongation in isolated nucleoli incubated with BrUTP was terminated. The release of inhibition enabled the immediate elongation, and the starting sites of BrUTP incorporation were identified by immunogold labelling detection method [13]. Therefore, COR efficiently inhibits premature rRNA elongation and can be used to control the transcriptional reaction. In addition, COR-TP, which exhibits a high level of structural similarity to ATP, may be derived from COR before directly blocking RNA synthesis in mutant Saccharomyces cerevisiae [8], and COR interferes with the efficiency of mRNA polyadenylation rather than terminating mRNA elongation [6]. Mechanistically, the structure of human poly(A) polymerase $\gamma$, which catalyzes the polyadenylation of mRNA, is identified using COR-TP (chain terminator) and $\mathrm{Ca}^{2+}$ (divalent cation) which bind to the active site of poly(A) polymerase $\gamma$ [114]. The binding of COR-TP and $\mathrm{Ca}^{2+}$ to poly(A) polymerase $\gamma$ may contribute to illuminating the reasons of COR-induced eryptosis in a $\mathrm{Ca}^{2+}$-dependent manner [115] and the COR-TP-mediated interruption of polyadenylation [58]. Hence, COR and COR-TP are considered specific inhibitors of RNA synthesis in various applications, such as the use of COR to investigate of the amounts of rhythmic RNAs [116]. 


\section{Pros and Cons of COR in Clinical Applications}

\subsection{Pros of COR in Clinical Applications}

COR exerts curative effects, including significant $(+++)$, less pronounced $(++)$, slight $(+)$ and no curative potency(-), on different types of diseases by affecting many molecular targets involved in various cellular signaling processes. A number of the advantages of COR in clinical applications are shown in Table 1.

Table 1. Pros of COR in clinical applications.

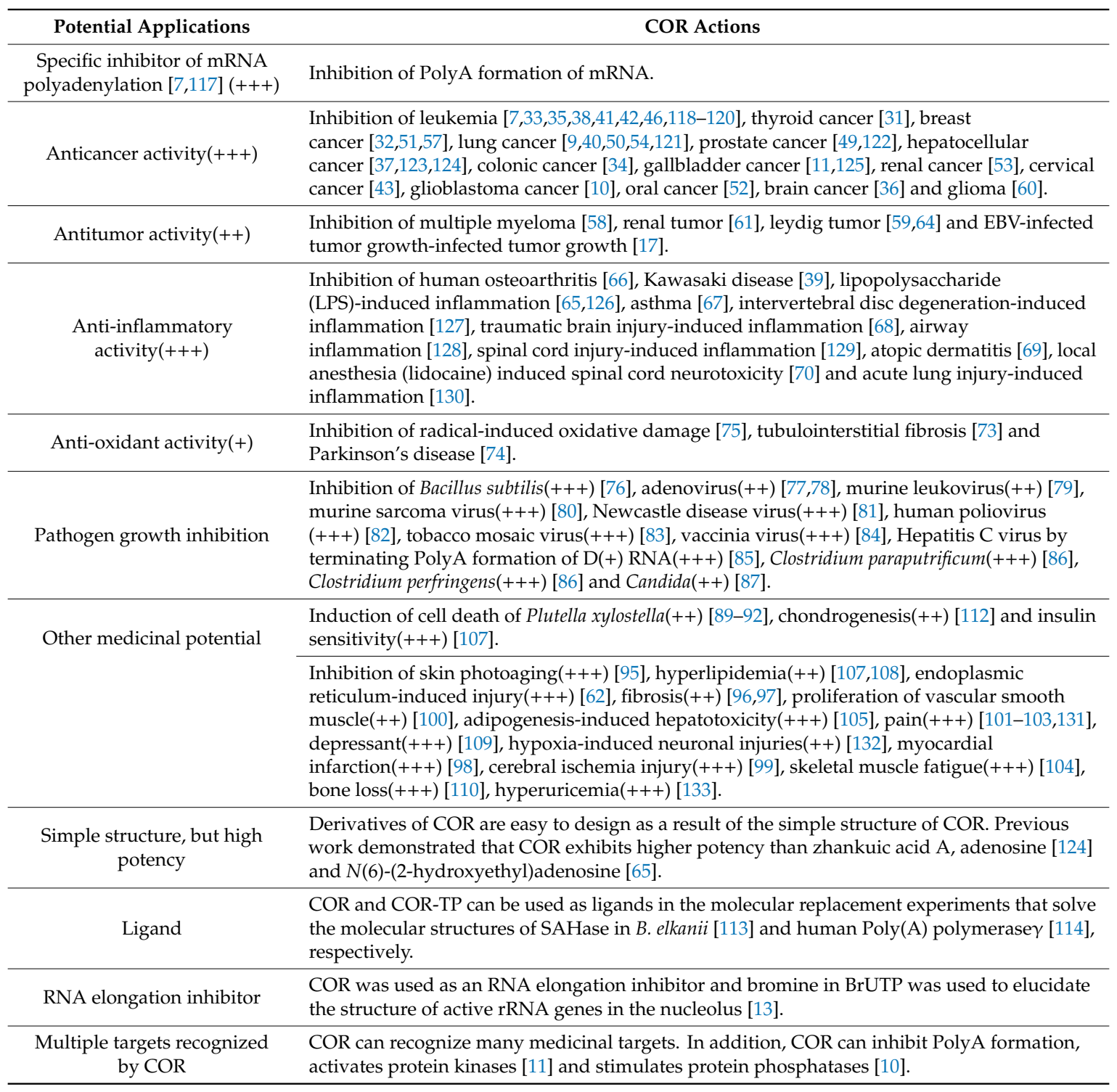

\subsection{Cons of COR in Clinical Applications}

(a) Possible toxicity to healthy cells: COR is toxic to malignant cancer cells [57] and nontoxic to healthy cells $[54,134]$. However, previous have also stated that COR exhibits toxicity towards healthy erythrocytes [115] and impairs healthy organs (liver, and kidney) in vivo in mice [91].

(b) Unfavorable pharmacokinetics: Since COR quickly loses its activity due to in vivo ADA and stomach acid conditions [24], COR has a short half-life and is rapidly eliminated [135]. The resistance of ADA to COR represents a significant issue because ADA can deaminize the adenosine analog COR. 
(c) Low solubility in water: The solubility of COR plays a vital role in drug storage and efficient therapeutic efficiency. The low solubility of COR in water causes low chemical stability, poor oral bioavailability and low cellular uptake. Previous work demonstrated that phosphate-buffered saline (PBS, $\mathrm{pH} 4.0$ ) is a suitable solvent for COR in intravenous and oral treatments at low doses. Propylene glycol (PPG) is more applicable than PBS at pH 4.0 as a COR solvent for oral treatments [136].

(d) Complex mechanisms of action: COR inhibits and/or induces multiple medicinal targets in a dose-dependent, condition-dependent and nonspecific manner: Different concentrations of COR exhibit diverse effects on MA-10 mouse Leydig tumor cells (MLTCs). A low concentration of COR activates the caspase-3/caspase-6/caspase-7/caspase-8/PARP pathway in MMLTCs, while a high dose of COR markedly increases the levels of p-AKT and p-mTOR and stimulates only caspase-3 rather than caspase-6/caspase-7/caspase-8 [59]. In addition, since COR is less reactive to PARP than to a specific inhibitor of PARP, COR is considered to exhibit PARP-inhibitory activity rather than specifically inhibit PARP [57]. In addition, COR exerts bidirectional regulatory activity under disparate stress-induced conditions [61,62] and in different cell types [59,61].

(e) Drug resistance: Multidrug resistance, one of the major obstacles, markedly decreases the curative potency of anticancer agents and the treatment of other diseases.

(f) Clinical safety and potency: The safety and efficacy of COR as a TdT-positive leukemia treatment is currently being evaluated in phase II clinical trials [137]. Currently, the clinical application of COR in the treatment of TdT-positive leukemia is not permitted.

\subsection{Medicinal Strategies for Promoting COR Efficiency and Safety}

(a) Inhibition of deamination by ADA. Three strategies have been used to approach this problem. (i) combined use of COR and ADA inhibitor; (ii) natural and designed ADA-resistant derivatives of COR; and (iii) nanocarrier for ADA-resistance. In strategy i, the combination of COR and an ADA inhibitor markedly improves the stability of COR. Efficient ADA inhibitors, such as actinomycin D [116], erythro-9-(2-hydroxy-3-nonyl)-adenine [135] and PTN [24], significantly enhance the bioavailability of COR. In strategy ii, multiple natural derivatives of COR in mushrooms [29] and their therapeutic value [138] have been extensively reviewed. In addition, designed ADA-resistant derivatives of COR can overcome treatment failure, such as the high bioavailability pro-cordycepin( $N$-acyloctanoylcordycepin), which is 4(time of maximum concentration)/30(maximum concentration)/68(area under concentration) times higher than that of COR [139], and ADA-resistant 2-fluoro-3'-deoxyadenosine has similar cytotoxicity $\left(\mathrm{IC}_{50}\right)$ values of $2.44 \pm 0.69 \mu \mathrm{M}$ (this compound alone) and $2.13 \pm 0.87 \mu \mathrm{M}$ (this compound co-incubated with ADA inhibitor PTN) while COR has markedly different $\mathrm{IC}_{50}$ values of $0.10 \pm 0.03 \mu \mathrm{M}(\mathrm{COR}$ co-existing with PTN) and over $100 \mu \mathrm{M}$ (COR alone) on MOLT4 cells in vitro [140]. Interestingly, an efficient and eco-friendly biotransformation system for generating $5^{\prime}$-O-acetylcordycepin at the 25-g scale and a 96.2\% isolated yield in solvent 2-methyltetrahydrofuran was developed, and Novozym 435 (an immobilized Candida antarctica lipase B) used in this system retains 63\% of its original activity after 7 recycling batches [141]. In strategy iii, a nanocarrier composed of layered double hydroxides was developed to prevent COR from deamination by ADA, such as [Mg-Al-cordycepin] nanohybrids. At the same concentration, this nanohybrid inhibit the growth of U937 cells at a rate that is 3.185 times higher than that of COR [142].

(b) Bypassing gastric acid conditions. The bioactivity of COR quickly decreases under gastric acid conditions. Hence, COR carriers, including gelatin type A nanoparticles [134] and transferrin-conjugated liposomes [143] have been developed to approach this problem.

(c) Decreasein toxicity. Several potential strategies are available to decrease the toxicity of COR: (i) low dose of treatment; (ii) natural and designed derivates; (iii) COR carriers for region-targeted treatment and the specific accumulation of COR. In strategy $i$, an appropriate dose of COR should be selected. In strategy ii, few studies have discovered and designed novel derivatives of COR, 
such as designed $\mathrm{N}$-octanoylcordycepin which exhibits lower metabolic velocity and higher bioavailability than COR [139]. In strategy iii, appropriate region-targeted drug carriers, such as transferrin-conjugated liposomes for COR delivery to liver cancer cells [143] and gelatin type A nanoparticle for COR delivery to lung cancer cells [134], increase the specific accumulation of $\mathrm{COR}$ at the desired region, decrease the total dose of $\mathrm{COR}$ and reduce unintended extravasation into healthy regions.

(d) Overcoming drug resistance. Drug resistance presents a serious challenge when diseased cells develop resistance to COR over time through various mechanisms that markedly reduce the curative potency of COR. Previous work uncovered several mechanisms of novel drug resistance, such as extracellular vesicles that mediate drug resistance due to direct exportation [144], cytotoxic drugs sequestration [145], and decreased effective concentration of the drug. COR resistance can be promoted through extracellular vesicle-mediated pathways. In addition, the combination of $\mathrm{COR}$ and other agents can efficiently overcome drug resistance. Water or ethanol extract rich in COR of fruiting bodies and/or mycelium of C. militaris (ER-COR) is also a potential strategy to conquer drug resistance.

(e) The low cost and high potency of ER-COR. The proliferation of renal carcinoma cells is more efficiently suppressed by the ER-COR from FB-CM than the ER-COR from mycelia [119]; moreover, ER-COR stimulated apoptosis more effectively than COR alone in vitro in human leukemia cells [53]. These effects may also be due to other components of FB-CM, such as PTN [24] and adenosine. In addition, ER-COR can strengthen immunity by increasing the level of cytokines (IL-2/IFN- $\gamma /$ TNF- $\alpha$ ) in vitro in splenocytes and cytokines (IL-2/IFN- $\gamma /$ TNF- $\alpha /$ IL-10) in vivo in immunosuppressed mice [146]. Nevertheless, the bioactive components of ER-COR are distinct due to their recognition of different targets. In vitro studies of human hepatocellular carcinoma cells revealed that the inhibitory effects of COR on ERp57 are more efficient than those of zhankuic acid A and adenosine, while the inhibition of PGK- 1 mediated by COR is less pronounced than that mediated by zhankuic acid A and adenosine [124].

\section{Metabolic Mechanisms of COR in COR-Producing Fungi}

\subsection{Scientific Name of the Caterpillar Fungus Called DongChongXiaCao in Chinese}

The teleomorph and anamorph of DongChongXiaCao have been scientifically named according to the rule "One Fungus=One Name" [147]. Although the teleomorph of DongChongXiaCao was previously named Sphaeria sinensis Berk. [148] and Cordyceps sinensis (Berk.) Sacc. [149,150], Ophiocordyceps sinensis is the modern taxonomic name for DongChongXiaCao [151]. This fungus is found only on the Qinghai-Tibet Plateau of China [152]. Although approximately twenty names have been used in the past [153], Hirsutella sinensis is the scientific name of the anamorph of DongChongXiaCao [154].

\subsection{COR-Producing Fungi}

Cordyceps and Ophiocordyceps are the primary COR-producing fungi (Table 2). The C. militaris fungus produces a higher level of COR than other fungi. Mutant G81-3 [22] and wild CICC 14014 [155] strains of $C$. militaris produced a maximum of 14,300 and $7350 \mu \mathrm{g} / \mathrm{mL}$ COR, which would be efficient for industrial applications. Notably, the total amino acid content of the mycelia of $O$. sinensis, which does not contain detectable levels of COR, exceeds that of the FB-CM. The COR content in the FB-CM reached $1.743 \mathrm{mg} / \mathrm{g}$, while no COR [156] or trace amounts of COR [157] were detected in the fruiting body of $O$. sinensis. In addition, the fruiting bodies of both C. sinensis and Ophiocordyceps xuefengensis, which are very similar [158], produce trace amounts of COR [159,160]. Intriguingly, previous work has emphasized that massive amounts of COR is produced during the development of FB-CM but not during the development of the mycelia [24]. Therefore, a comparative analysis of similar groups (Cordyceps vs Ophiocordyceps) or the same fungus at different development phases would 
contribute to the elucidation of the key factors involved in COR metabolic pathways(biosynthesis and cellular detoxification).

Table 2. COR production of different strains of Cordyceps and Ophiocordyceps from 2007 to 2018.

\begin{tabular}{|c|c|c|c|c|c|c|}
\hline Strain & Strain ID & Yield & \multicolumn{2}{|c|}{ Mesurement } & Strain Source & References \\
\hline $\mathrm{CM}$ & (W)NBRC 9787 & 2500 & $\mathrm{AL}$ & $\mathrm{D}$ & NITE, Japan & [161] \\
\hline $\mathrm{CM}$ & (M)G81-3 & 8570 & $\mathrm{AL}$ & $\mathrm{D}$ & UF, Japan & [162] \\
\hline $\mathrm{CM}$ & (W)- & 2.276 & BS & $\mathrm{E}$ & UM-SAR, China & [163] \\
\hline $\mathrm{CM}$ & (M)G81-3 & 8600 & $\mathrm{AL}$ & $\mathrm{D}$ & UF, Japan & [164] \\
\hline $\mathrm{CC}$ & $(\mathrm{W})-$ & 1.398 & BS & $\mathrm{E}$ & SNJM-HB, China & [165] \\
\hline $\mathrm{CM}$ & (W)- & 1.743 & BS & $\mathrm{E}$ & FNS and IE-UHF & [156] \\
\hline $\mathrm{CM}$ & (W)14014 & 7350 & $\mathrm{AL}$ & $\mathrm{D}$ & CCICC, China & [155] \\
\hline $\mathrm{CM}$ & (M)G81-3 & 14300 & $\mathrm{AL}$ & $\mathrm{D}$ & UF, Japan & [22] \\
\hline $\mathrm{CM}$ & $(\mathrm{W})-$ & 7.04 & BS & $\mathrm{E}$ & MDU, Taiwan & [166] \\
\hline CS & (W)- & $0.0068-0.029$ & BS & $\mathrm{E}$ & $\mathrm{QH}, \mathrm{HB}$ and $\mathrm{AH}$, china & [159] \\
\hline $\mathrm{CM}$ & (W)BCRC 32219 & 1.7 & $\mathrm{AL}$ & $\mathrm{D}$ & BCRC, Hsinchu, Taiwan & [167] \\
\hline $\mathrm{CM}$ & (W)NBRC 10352-3 & 6200 & $\mathrm{AL}$ & $\mathrm{D}$ & SU, Japan & [168] \\
\hline OX & (W)HACM 001 & 0.0371 & BS & $\mathrm{E}$ & XFM-HN, China & [160] \\
\hline CM & (Md)KACC44455+SPNU1 & 6.63 & BS & $\mathrm{E}$ & KACC and SPNU, Korea & [169] \\
\hline $\mathrm{CM}$ & (W)NBRC 103752 & 4920 & $\mathrm{AL}$ & $\mathrm{D}$ & BRC, NITE, Tokyo, Japan & [170] \\
\hline CK & (GS)Y9 & 0.7135 & AS & $\mathrm{C}$ & SDU, China & [171] \\
\hline $\mathrm{CM}$ & (W)CGMCC 3.16321 & 5.56 & BS & $\mathrm{E}$ & Beijing, China & [172] \\
\hline CM & (W)BCRC34380 & 3483 & $\mathrm{AL}$ & C & Hsinchu, Taiwan & [173] \\
\hline $\mathrm{CP}$ & (W)GZUCC 8552 & 5.311 & AS & C & BM, Guizhou, China & [174] \\
\hline $\mathrm{CM}$ & (W)CGMCC 3.16321 & 5.56 & BS & $\mathrm{E}$ & Beijing, China & [172] \\
\hline CM & (W)No.20130508 & 9.45 & BS & $\mathrm{E}$ & Nanjing, China & [23] \\
\hline PH & (W)Isolated strain & 0.0346 & $\mathrm{AL}$ & $\mathrm{D}$ & Qinghai, China & [175] \\
\hline
\end{tabular}

Note: CM: Cordyceps militaris. CC:Cordyceps cicadae. CS:Cordycepssinensis. OX: Ophiocordycepsxuefengensis. CK: Cordycepskyushuensis. CP: Cordycepspruinosa. PH: Paecilomyces hepialid. A: liquid fermentation. B: solid fermentation. C: mycelia. D: extracellular. E: fruiting body. L: $\mu \mathrm{g} / \mathrm{mL}$. S: $\mathrm{mg} / \mathrm{g}$. (W): wild strain. (M): mutant strain. (GS): genome shuffling strain. (Md): mated strain. A+B: mycelia of strain A mated with strain B. NITE: National Institute of Technology and Evaluation. BRC: Biological Research Center. UF: University of Fukui. SNJM-HB: Shennongjia Mountains, Hubei Province. FNS: Faculty of Natural Sciences. IE-UHF: Institute of Evolution, University of Haifa. CCICC: The China Center of Industrial Culture Collection. MDU: Mingdao University. QH: QinghaiProvince, China. HB: HubeiProvince, China. AH: Anhui Province, China. BCRC: Bioresource Collection and Research Center. SU: Shizuoka University. XFM-HN: Xuefeng Mountains in Hunan Province. KACC: Korean Agricultural Culture Collection. SPNU: Systems Plant Microbiology Laboratory of Pusan National University. SD: Shandong University. BM: Leigong Mountains. UM-SAR: University of Macau, Macau SAR.

\subsection{COR Metabolic Mechanisms in C. militaris under Hypoxia, Light and Heat Stress}

The mycelia of $C$. militaris obtained under liquid surface culture conditions produced a higher level of COR than the mycelia obtained under a submerged culture condition [22]. Mechanistically, cytochrome P450 oxidoreductases, including heme, are markedly enriched in the static liquid surface culture, which indicate a hypoxic condition. Hypoxic conditions significantly increase the levels of hypoxia-associated proteins, adenylosuccinate synthase and phosphoribosyl-aminoimidazolesuccino-carboxamide synthase involved in purine nucleotide metabolism [170]. Similar results that hypoxia stress significantly promoted gene expansion of cytochrome P450 were observed during the fruiting of O. sinensis [176]. Since COR can modulate intracellular ROS levels in diseased and healthy cells, COR biosynthesis may be associated with intracellular ROS modulation in C. militaris. The detailed mechanism requires further investigation.

Certain types of light can induce COR biosynthesis via photoacceptor-mediated signal pathways in C. militaris. Studies have demonstrated that the regulation of COR biosynthesis in C. militaris is associated with blue-light receptors, including Cmwc-1(wc-1 in C. militaris) and CmCRY-DASH (CRY-DASH in C. militaris). Cmwc-1 upregulates adenylosuccinate synthase by 4 -fold and significantly downregulates ADA in wild C. militaris $[177,178]$, suggesting that this factor has a positive effect on COR biosynthesis. Thus, CmCRY-DASH, required for FB-CM development, impairs COR biosynthesis in a Cmwc-1-interdependent manner [179]. In addition, in C. militaris, the production of COR is markedly increased under heat stress conditions compared with normal conditions as a result of the upregulation of CCM_04437, which encodes a metal-dependent phosphohydrolase, and CCM_04438, which encodes adenosine-triphosphate phosphoribosyl- transferase [172]. 


\subsection{Metabolic Mechanisms of COR in C. militaris and O. sinensis}

COR biosynthetic mechanism: The biosynthetic mechanism of COR involved in purine biosynthesis has attracted broad interest in the past seven decades. Previous work indicated that adenine [180] and adenosine [181] are the direct precursors of COR biosynthesis and that the biosynthesis of COR may resemble that of 2'-deoxynucleotides [182]. Based on the whole genome sequence of C. militaris [183], COR is speculated to be produced through both de novo synthesis and a salvage pathway. In studies that examined COR biosynthesis in C. militaris, adenylosuccinate synthase, encoded by iron-induced purA, induced the formation of inosine monophosphate (IMP) which increased the level of AMP, and COR is subsequently produced from AMP [184]. Similar work demonstrated that COR may be formed from adenosine and its derivatives (AMP and adenosine-diphosphate) during purine biosynthesis in C. militaris [185]. In addition, COR may also be generated from ribonucleotides in a reaction catalyzed by ribonucleotide reductases (RNRs) in species of Cordyceps [186,187]. Thus, RNRs specifically catalyze the transformation of nucleotides to $2^{\prime}$-deoxynucleotides rather than the transformation of nucleotides to $3^{\prime}$-deoxynucleotides [188]. Previous studies that investigated $O$. sinensis found that adenosine may be phosphorylated by adenosine kinase before reduction by RNRs in the fruiting body [157]. As a result of the comparative analysis of C. militaris and O. sinensis, it is speculated that COR is most likely produced via the phosphorylation of adenosine prior to the unclear reduction process. Notably, the biosynthesis of COR was completely described by comparing the conserved genes involved in the COR biosynthetic pathway of two COR-producing and distantly related fungi (A. nidulans [25] and C. militaris). Mechanistically, the cns1 and cns2 enzymes cocatalyze COR biosynthesis. The Cns3 enzyme first catalyzes the reaction that changes adenosine into adenosine-3'-monophosphate ( $\left.3^{\prime} \mathrm{AMP}\right)$. Next, $2^{\prime}$-carbonyl-3'-deoxyadenosine $\left(2^{\prime}-\mathrm{C}-3^{\prime}-\mathrm{dA}\right)$ is generated through the dephosphorylation of $3^{\prime}-\mathrm{AMP}$ by Cns2. Finally, COR is produced from $2^{\prime}-\mathrm{C}-3^{\prime}-\mathrm{dA}$ by Cns1 [24].

The cellular detoxification of COR in C. militaris: Several potential pathways contribute to the cellular detoxification of COR, including deamination by ADA, decreased intracellular PTN, removal of PTN/COR out by transporters, and conversion of COR. Three out of the eight putative purine deaminases encoded by genes in C. militaris (CCM_07169,CCM_09449 and CCM_02911) are similar to SanADA3 [189]. Deaminases encoded by genes in C. militaris (CCM_09449 and CCM_02911) resemble human liver ADA1 [24], which can efficiently deaminate COR in vitro in C57BL/6 mouse erythrocytes [190]. Thus, the ADA that targets COR in C. militaris remain unknown. In addition, PTN, which is transported by the adenosine-triphosphate-binding cassette (ABC) transporter Cns 4 and is expressed only in the FB-CM, not the mycelia, can prevent the deamination of COR by ADA through a Cns3-mediated process [24]. In most cases, drug transporters pump superabundant toxic metabolites, such as COR and PTN, out of cells to decrease cellular detoxification; however, the identity of the COR transporter remains unclear. In addition, toxic COR may be converted to other components, such as COR-TP. Thus, few studies have revealed the mechanisms of COR conversion.

\subsection{Comparative Analysis of the COR-Associated Mechanisms Involved in the Fruiting Body of C. militaris and $O$. sinensis}

Signal transduction in the fruiting body: Pheromone receptors, such as GPCRs, regulate fungal fruiting-body formation. It is speculated that GPCR-mediated signaling pathways play an important role in fruiting-body development. The cAMP-dependent protein kinase A (PKA) and MAPK pathways, as well as many transcription factors ( $\mathrm{C} 2 \mathrm{H} 2$ zinic fingers), are involved in the fruiting of O. sinensis; however, GPCR signaling are not involved [157]. In the development of the fruiting-body of C. militaris, signal transduction is markedly more active in FB-CM than mycelia [191], suggesting a possible relationship between the COR metabolic pathway and signal transduction. GPCRs, MAPK and cAMP-dependent PKA signaling and the major transcription factor (Zn2Cys6) all exist in the fruiting body of C. militaris. Notably, the level of GPCRs significantly increased during initial fruiting, and MAPK signaling plays a more important role than PKA in FB-CM development [183]. Considering 
that the $O$. sinensis fungus retains a rather low COR-producing capacity while the fruiting body of C. militaris can produce abundant COR, comparing the differential signaling involved in the fruiting development between $O$. sinensis and C. militaris, GPCRs are expressed only in the fruiting body of C. militaris, suggesting a potential relationship between COR metabolism and GPCRs. It is speculated that COR may be biosynthesized at the initial fruiting phase and transported into the extracellular matrix. Then, COR functions through an extracellular signaling may induce GPCRs and associated cascade reaction in initial fruiting of $C$. militaris, which in turn regulates COR metabolism. In other words, GPCR signaling pathways may play vital roles in COR metabolism. This hypothesis requires further verification.

Gene expression during fruiting: A large amount of COR is produced during fruiting, and the COR content in the fruiting body significantly exceeds that in mycelia. COR, as a bioactive component with multiple functions, may be produced to help fungi survive disadvantageous factors (infection and environmental extremes) and to form fruiting bodies. The gene expression levels of two species are markedly different during fruiting. The number of protein-coding genes (9684) in FB-CM [183] is larger than that (7939) in the fruiting body of $O$. sinensis [176]. The number of peroxidase genesis significantly exceeded in O. sinensis compared with $C$. militaris, suggesting a higher ROS-scavenging ability in O. sinensis. Additionally, haloperoxidase (heme) accounts for the most abundant among peroxidase genes (rough 16.67\%) in O. sinensis. Although the amount of proteases in O. sinensis is fewer than that in C. militaris, a signal peptide, implicated in pathogen-host interactions, in $O$. sinensis obviously exceeds that in C. militaris, indicating a stronger interactions between pathogen and host in O. sinensis [176]. Mechanistically, after insect hosts are infected by fungi, the insects produce large amounts of ROS to kill the pathogenic fungi that simultaneously develop ROS-scavenging capacity [192], for example, by increasing peroxidase expression in O. sinensis and by promoting COR biosynthesis in both fungi. It is speculated that the $C$. militaris fungus may rapidly produce many COR molecules to defend against unfavorable factors caused by insect hosts. In contrast, although the $O$. sinensis fungus retains a COR-producing capacity, trace amounts of COR can not efficiently suppress insect-induced injury, which directly results in increased ROS-scavenging peroxidases and pathogen-host interactions.

Fruiting of $O$. sinensis: $O$. sinensis was successfully obtained through artificial cultivation by Sunshine Lake Pharma Co. Ltd. (Guangdong, China) [193]. Phylogenetic analysis revealed O. sinensis and host insects originate at the same time and in similar geographic regions, southern Tibet/Yunnan, China, suggesting a strong coevolution between host and parasite $[194,195]$. However, the coevolution mechanisms remain unclear. Therefore, the following two issues still exist and need further investigation: (i) the genetic coevolution of $O$. sinensis and host insects; (ii) the relationship between COR metabolism and fruiting-body formation.

\section{Summary and Outlook}

Medicinal fungi produce a variety of bioactive metabolites which have medicinal potential for treating human diseases. These natural metabolites, such as COR, are more readily accepted as therapy by people and easy to obtain. Natural products of secondary metabolites that have the potential to treat human diseases have been extensively reviewed [196]. The challenge is to investigate the fermentation conditions and mutant strains for large-scale production. In addition, new natural products derived from medicinal fungi require further investigation. Recent technologies have been developed to enable the discovery of new drugs, including comparative metabolomics technologies [197]. Considering the possible toxicity, resistance and efficiency of these potential drugs, designed derivatives of natural products, such as ADA-resistant and low-toxicity COR, as well as organ-targeted nanoparticles for COR delivery in vivo therapy, are also needed. Notably, a high-throughput and efficient nanomole-scale system for synthesizing analogs of drugs has been developed. The nanomole-scale system can simultaneously rank the affinity between analogs and targets without the need for purification via mass spectrometry [198]. 
To date, although the mechanism of COR biosynthesis in C. militaris has been completely described, some topics require further investigation in C. militaris, such as the COR transport mechanism of COR, ADA that deaminates COR, gene function of cns4, natural and mutant strains that produce high levels of COR, GPCR signaling in COR metabolic pathway and effect of COR on fruiting development.

The heterogeneity of cancer cells has historically represented a challenge for cancer research. To address this problem, single-cell analysis technologies have been developed in recent years. The development of single-cell analysis technologies based on single-cell isolation methods will remove the limitations in traditional technologies, such as single-cell sequencing technology in cancer research [199] and gene regulation [200]. Intriguingly, a new single-cell RNA-sequencing technology, which cost only $\$ 0.01$ per cell and requires basic laboratory conditions, was developed [201]. Furthermore, the ability of single-cell imaging technologies to investigate the actions of drugs has been systematically reviewed [202]. Recently, a sensitive, specific, efficient fluorescent acetylcholine indicator for monitoring cholinergic action in vivo or in vitro biological processes was developed [203]. We posit that future research on COR will be greatly improved using single-cell analysis technologies, suitable fluorescent indicators and imaging technologies. In brief, the goal of single-cell analysis, including single-cell sequencing, in understanding the action of COR is to overcome the issues of cellular heterogeneity from collective cell populations that can only exhibit the average level of these heterogeneous cells, and the outcome is to understand the true mechanisms of COR action in both disease' cells and COR-producing cells.

Supplementary Materials: The following are available online. Table S1: Anti-cancer potential of COR, Table S2: Anti-tumor potential of COR, Table S3: Anti-inflammatory and anti-oxidant potential of COR, Table S4: COR inhibiting polyadenylation of mRNA in pathogens, Table S5: Other medicinal value and biotechnological applications.

Author Contributions: Conceptualization, X.-K.L. and H.Y.; methodology, P.Q., X.-K.L. and H.Y.; software, P.Q.; validation, X.-K.L., H.Y. and Z.-Y.W.; formal analysis, X.-K.L., H.Y. and Z.-Y.W.; investigation, P.Q., and X.-K.L.; resources, Z.-Y.W. and D.-X.L.; data curation, P.Q.; writing-original draft preparation, P.Q. and Z.-Y.W.; writing - review and editing, X.-K.L. and H.Y.; visualization, P.Q.; supervision, H.Y., Z.-Y.W. and D.-X.L.; project administration, P.Q., Z.-Y.W. and D.-X.L.; funding acquisition, P.Q., Z.-Y.W. and D.-X.L.

Funding: This research was funded by the youth science and technology foundation program of Gansu Province of China, grant number 17JR5RA181; The application research and development project of Gansu Academy of Sciences of China, grant number 2017JK-14; National Natural Science Foundation of China, grant number 31560037; Innovation Group Project for Gansu Province of China, grant number 1606RJA325; Innovation Team Construction Fund for Gansu Academy of Sciences of China, grant number 2016TD-1.

Acknowledgments: We are grateful to Zhi-Ye Wang for extensive efforts and a large amount of work on this paper, including manuscript preparation, data analysis and some pivotal revisions.

Conflicts of Interest: The authors declare no conflict of interest.

\section{References}

1. Latest Global Cancer Data in 2018. Available online: http://www.iarc.fr/en/media-centre/pr/2018/pdfs/pr263_E.pdf (accessed on 12 September 2018).

2. Chen, W.; Zheng, R.; Baade, P.D.; Zhang, S.; Zeng, H.; Bray, F.; Jemal, A.; Yu, X.Q.; He, J. Cancer statistics in China, 2015. Ca Cancer J. Clin. 2016, 66, 115-132. [CrossRef] [PubMed]

3. Frederiksen, S.; Malling, H.; Klenow, H. Isolation of 3'-deoxyadenosine (cordycepin) from the liquid medium of Cordyceps militaris (L. ex Fr.) Link. Biochim. Et Biophys. Acta (Bba)-Nucleic Acids Protein Synth. 1965, 95, 189-193. [CrossRef]

4. Cunningham, K.G.; Manson, W.; Spring, F.S.; Hutchinson, S.A. Cordycepin, a metabolic product isolated from cultures of Cordyceps militaris (Linn.) Link. Nature 1950, 166, 949. [CrossRef] [PubMed]

5. Wong, Y.Y.; Moon, A.; Duffin, R.; Barthet-Barateig, A.; Meijer, H.A.; Clemens, M.J.; de Moor, C.H. Cordycepin inhibits protein synthesis and cell adhesion through effects on signal transduction. J. Biol. Chem. 2010, 285, 2610-2621. [CrossRef] [PubMed] 
6. Holbein, S.; Wengi, A.; Decourty, L.; Freimoser, F.M.; Jacquier, A.; Dichtl, B. Cordycepin interferes with 3' end formation in yeast independently of its potential to terminate RNA chain elongation. RNA 2009, 15, 837-849. [CrossRef] [PubMed]

7. Levenson, R.; Kernen, J.; Housman, D. Synchronization of MEL cell commitment with cordycepin. Cell 1979, 18, 1073-1078. [CrossRef]

8. Holbein, S.; Freimoser, F.M.; Werner, T.P.; Wengi, A.; Dichtl, B. Cordycepin-hypersensitive growth links elevated polyphosphate levels to inhibition of poly(A) polymerase in Saccharomyces cerevisiae. Nucleic Acids Res. 2008, 36, 353-363. [CrossRef]

9. Wang, Z.; Wu, X.; Liang, Y.N.; Wang, L.; Song, Z.X.; Liu, J.L.; Tang, Z.S. Cordycepin Induces Apoptosis and Inhibits Proliferation of Human Lung Cancer Cell Line H1975 via Inhibiting the Phosphorylation of EGFR. Molecules 2016, 21, 1267. [CrossRef]

10. Hueng, D.Y.; Hsieh, C.H.; Cheng, Y.C.; Tsai, W.C.; Chen, Y. Cordycepin inhibits migration of human glioblastoma cells by affecting lysosomal degradation and protein phosphatase activation. J. Nutr. Biochem. 2017, 41, 109-116. [CrossRef]

11. Wu,W.D.; Hu, Z.M.; Shang, M.J.; Zhao, D.J.; Zhang, C.W.; Hong, D.F.; Huang, D.S. Cordycepin down-regulates multiple drug resistant (MDR)/HIF-1 $\alpha$ through regulating AMPK/mTORC1 signaling in GBC-SD gallbladder cancer cells. Int. J. Mol. Sci. 2014, 15, 12778-12790. [CrossRef]

12. Tuli, H.S.; Sandhu, S.S.; Sharma, A.K. Pharmacological and therapeutic potential of Cordyceps with special reference to Cordycepin. 3 Biotech. 2013, 4, 1-12. [CrossRef] [PubMed]

13. Cheutin, T.; O’Donohue, M.; Beorchia, A.; Vandelaer, M.; Kaplan, H.; Defever, B.; Ploton, D.; Thiry, M. Three-dimensional organization of active rRNA genes within the nucleolus. J. Cell Sci. 2002, 115, 3297-3307. [PubMed]

14. Sakaguchi, S.; Fukuda, T.; Takano, H.; Ono, K.; Takio, S. Photosynthetic electron transport differentially regulates the expression of superoxide dismutase genes in liverwort, Marchantia paleacea var. diptera. Plant. Cell Physiol. 2004, 45, 318-324. [CrossRef] [PubMed]

15. Eberhardt, W.; Huwiler, A.; Beck, K.F.; Walpen, S.; Pfeilschifter, J. Amplification of IL-1-Induced Matrix Metalloproteinase-9 Expression by Superoxide in Rat Glomerular Mesangial Cells Is Mediated by Increased Activities of NF-B and Activating Protein-1 and Involves Activation of the Mitogen-Activated Protein Kinase Pathways. J. Immunol. 2000, 165, 5788-5797. [PubMed]

16. Bommareddy, A.; Hahm, E.R.; Xiao, D.; Powolny, A.A.; Fisher, A.L.; Jiang, Y.; Singh, S.V. Atg5 regulates phenethyl isothiocyanate-induced autophagic and apoptotic cell death in human prostate cancer cells. Cancer Res. 2009, 69, 3704-3712. [CrossRef] [PubMed]

17. Du, Y.; Yu, J.; Du, L.; Tang, J.; Feng, W.H. Cordycepin enhances Epstein-Barr virus lytic infection and Epstein-Barr virus-positive tumor treatment efficacy by doxorubicin. Cancer Lett. 2016, 376, 240-248. [CrossRef] [PubMed]

18. Yao, L.H.; Huang, J.N.; Li, C.H.; Li, H.H.; Yan, W.W.; Cai, Z.L.; Liu, W.X.; Xiao, P. Cordycepin suppresses excitatory synaptic transmission in rat hippocampal slices via a presynaptic mechanism. Cns Neurosci. 2013, 19, 216-221. [CrossRef] [PubMed]

19. Jin, M.L.; Park, S.Y.; Kim, Y.H.; Oh, J.I.; Lee, S.J.; Park, G. The neuroprotective effects of cordycepin inhibit glutamate-induced oxidative and ER stress-associated apoptosis in hippocampal HT22 cells. Neurotoxicology 2014, 41, 102-111. [CrossRef]

20. Kwon, H.W.; Shin, J.H.; Lim, D.H.; Ok, W.J.; Nam, G.S.; Kim, M.J.; Kwon, H.K.; Noh, J.H.; Lee, J.Y.; Kim, H.H.; et al. Antiplatelet and antithrombotic effects of cordycepin-enriched WIB-801CE from Cordyceps militaris ex vivo, in vivo, and in vitro. Bmc Complement. Altern. Med. 2016, 16, 508. [CrossRef]

21. Oztas, O.; Selby, C.P.; Sancar, A.; Adebali, O. Genome-wide excision repair in Arabidopsis is coupled to transcription and reflects circadian gene expression patterns. Nat. Commun. 2018, 9, 1503. [CrossRef]

22. Masuda, M.; Das, S.K.; Hatashita, M.; Fujihara, S.; Sakurai, A. Efficient production of cordycepin by the Cordyceps militaris mutant G81-3 for practical use. Process. Biochem. 2014, 49, 181-187. [CrossRef]

23. Lin, Q.; Long, L.; Wu, L.; Zhang, F.; Wu, S.; Zhang, W.; Sun, X. Evaluation of different agricultural wastes for the production of fruiting bodies and bioactive compounds by medicinal mushroom Cordyceps militaris. J. Sci. Food Agric. 2017, 97, 3476-3480. [CrossRef] [PubMed]

24. Xia, Y.; Luo, F.; Shang, Y.; Chen, P.; Lu, Y.; Wang, C. Fungal Cordycepin Biosynthesis Is Coupled with the Production of the Safeguard Molecule Pentostatin. Cell Chem. Biol. 2017, 24, 1479-1489. [CrossRef] [PubMed] 
25. Kodama, K.; Kusakabe, H.; Machida, H.; Midorikawa, Y.; Shibuya, S.; Kuninaka, A.; Yoshino, H. Isolation of 2'-Deoxycoformycin and Cordycepin from Wheat Bran Culture of Aspergillus nidulans Y176-2. Agric. Biol. Chem. 1979, 43, 2375-2377.

26. Tuli, H.S.; Sharma, A.K.; Sandhu, S.S.; Kashyap, D. Cordycepin: A bioactive metabolite with therapeutic potential. Life Sci. 2013, 93, 863-869. [CrossRef]

27. Tian, X.; Li, Y.; Shen, Y.; Li, Q.; Wang, Q.; Feng, L. Apoptosis and inhibition of proliferation of cancer cells induced by cordycepin. Oncol. Lett. 2015, 10, 595-599. [CrossRef]

28. Paterson, R.R. Cordyceps: A traditional Chinese medicine and another fungal therapeutic biofactory? Phytochemistry 2008, 69, 1469-1495. [CrossRef]

29. Phan, C.W.; Wang, J.K.; Cheah, S.C.; Naidu, M.; David, P.; Sabaratnam, V. A review on the nucleic acid constituents in mushrooms: Nucleobases, nucleosides and nucleotides. Crit. Rev. Biotechnol. 2018, 38, 762-777. [CrossRef]

30. Chen, Y.C.; Chen, Y.H.; Pan, B.S.; Chang, M.M.; Huang, B.M. Functional study of Cordyceps sinensis and cordycepin in male reproduction: A review. J. Food Drug Anal. 2017, 25, 197-205. [CrossRef]

31. Chen, Y.; Chen, Y.C.; Lin, Y.T.; Huang, S.H.; Wang, S.M. Cordycepin induces apoptosis of CGTH W-2 thyroid carcinoma cells through the calcium-calpain-caspase 7-PARP pathway. J. Agric. Food Chem. 2010, 58, 11645-11652. [CrossRef]

32. Choi, S.; Lim, M.H.; Kim, K.M.; Jeon, B.H.; Song, W.O.; Kim, T.W. Cordycepin-induced apoptosis and autophagy in breast cancer cells are independent of the estrogen receptor. Toxicol. Appl. Pharm. 2011, 257, 165-173. [CrossRef]

33. Jang, K.J.; Kwon, G.S.; Jeong, J.W.; Kim, C.H.; Yoon, H.M.; Kim, G.Y.; Shim, J.H.; Moon, S.K.; Kim, W.J.; Choi, Y.H. Cordycepin induces apoptosis through repressing hTERT expression and inducing extranuclear export of hTERT. J. Biosci. Bioeng. 2015, 119, 351-357. [CrossRef]

34. Lee, S.Y.; Debnath, T.; Kim, S.K.; Lim, B.O. Anti-cancer effect and apoptosis induction of cordycepin through DR3 pathway in the human colonic cancer cell HT-29. Food Chem. Toxicol. 2013, 60, 439-447. [CrossRef] [PubMed]

35. Liao, Y.; Ling, J.; Zhang, G.; Liu, F.; Tao, S.; Han, Z.; Chen, S.; Chen, Z.; Le, H. Cordycepin induces cell cycle arrest and apoptosis by inducing DNA damage and up-regulation of p53 in Leukemia cells. Cell Cycle 2015, 14, 761-771. [CrossRef] [PubMed]

36. Chaicharoenaudomrung, N.; Jaroonwitchawan, T.; Noisa, P. Cordycepin induces apoptotic cell death of human brain cancer through the modulation of autophagy. Toxicol. Vitr. 2018, 46, 113-121. [CrossRef] [PubMed]

37. Zeng, Y.; Lian, S.; Li, D.; Lin, X.; Chen, B.; Wei, H.; Yang, T. Anti-hepatocarcinoma effect of cordycepin against NDEA-induced hepatocellular carcinomas via the PI3K/Akt/mTOR and Nrf2/HO-1/NF-kB pathway in mice. Biomed. Pharm. 2017, 95, 1868-1875. [CrossRef]

38. Jeong, J.W.; Jin, C.Y.; Park, C.; Hong, S.H.; Kim, G.Y.; Jeong, Y.K.; Lee, J.D.; Yoo, Y.H.; Choi, Y.H. Induction of apoptosis by cordycepin via reactive oxygen species generation in human leukemia cells. Toxicol. Vitr. 2011, 25, 817-824. [CrossRef]

39. Zhang, J.L.; Xu, Y.; Shen, J. Cordycepin inhibits lipopolysaccharide(LPS)-induced tumor necrosis factor (TNF)- $\alpha$ production via activating amp-activated protein kinase (AMPK) signaling. Int. J. Mol. Sci. 2014, 15, 12119-12134. [CrossRef]

40. Hwang, J.H.; Park, S.J.; Ko, W.G.; Kang, S.M.; Lee, D.B.; Bang, J.; Park, B.J.; Wee, C.B.; Kim, D.J.; Jang, I.S.; et al. Cordycepin induces human lung cancer cell apoptosis by inhibiting nitric oxide mediated ERK/Slug signaling pathway. Am. J. Cancer Res. 2017, 7, 417-432.

41. Ko, B.S.; Lu, Y.J.; Yao, W.L.; Liu, T.A.; Tzean, S.S.; Shen, T.L.; Liou, J.Y. Cordycepin Regulates GSK-3b/b-Catenin Signaling in Human Leukemia Cells. PLoS ONE 2013, 8, e76320. [CrossRef]

42. Liu, F.C.; Lai, M.T.; Chen, Y.Y.; Lin, W.H.; Chang, S.J.; Sheu, M.J.; Wu, C.H. Elucidating the inhibitory mechanisms of the ethanolic extract of the fruiting body of the mushroom Antrodia cinnamomea on the proliferation and migration of murine leukemia WEHI-3 cells and their tumorigenicity in a BALB/c allograft tumor model. Phytomedicine 2013, 20, 874-882. [CrossRef] [PubMed]

43. Seong da, B.; Hong, S.; Muthusami, S.; Kim, W.D.; Yu, J.R.; Park, W.Y. Cordycepin increases radiosensitivity in cervical cancer cells by overriding or prolonging radiation-induced G2/M arrest. Eur. J. Pharm. 2016, 771, 77-83. [CrossRef] [PubMed] 
44. Naito, Y.; Yoshioka, Y.; Yamamoto, Y.; Ochiya, T. How cancer cells dictate their microenvironment: Present roles of extracellular vesicles. Cell. Mol. Life Sci. 2017, 74, 697-713. [CrossRef] [PubMed]

45. Sullivan, R.; Maresh, G.; Zhang, X.; Salomon, C.; Hooper, J.; Margolin, D.; Li, L. The Emerging Roles of Extracellular Vesicles As Communication Vehicles within the Tumor Microenvironment and Beyond. Front. Endocrinol. 2017, 8, 194. [CrossRef] [PubMed]

46. Liang, S.M.; Lu, Y.J.; Ko, B.S.; Jan, Y.J.; Shyue, S.K.; Yet, S.F.; Liou, J.Y. Cordycepin disrupts leukemia association with mesenchymal stromal cells and eliminates leukemia stem cell activity. Sci. Rep. 2017, 7, 43930. [CrossRef] [PubMed]

47. Mantovani, A.; Bottazzi, B.; Colotta, F.; Sozzani, S.; Ruco, L. The origin and function of tumor-associated macrophages. Immunol. Today 1992, 13, 265-270. [CrossRef]

48. Xing, F. ancer associated fibroblasts (CAFs) in tumor microenvironment. Front. Biosci. 2010, 15, 166.

49. Jeong, J.W.; Jin, C.Y.; Park, C.; Han, M.H.; Kim, G.Y.; Moon, S.K.; Kim, C.G.; Jeong, Y.K.; Kim, W.J.; Lee, J.D.; et al. Inhibition of migration and invasion of LNCaP human prostate carcinoma cells by cordycepin through inactivation of Akt. Int. J. Oncol. 2012, 40, 1697-1704.

50. Chen, Y.Y.; Chou, P.Y.; Chien, Y.C.; Wu, C.H.; Wu, T.S.; Sheu, M.J. Ethanol extracts of fruiting bodies of Antrodia cinnamomea exhibit anti-migration action in human adenocarcinoma CL1-0 cells through the MAPK and PI3K/AKT signaling pathways. Phytomedicine 2012, 19, 768-878. [CrossRef] [PubMed]

51. Noh, E.M.; Youn, H.J.; Jung, S.H.; Han, J.H.; Jeong, Y.J.; Chung, E.Y.; Jung, J.Y.; Kim, B.S.; Lee, S.H.; Lee, Y.R.; et al. Cordycepin inhibits TPA-induced matrix metalloproteinase-9 expression by suppressing the MAPK/AP-1 pathway in MCF-7 human breast cancer cells. Int. J. Mol. Med. 2010, 25, 255-260.

52. Su, N.W.; Wu, S.H.; Chi, C.W.; Liu, C.J.; Tsai, T.H.; Chen, Y.J. Metronomic Cordycepin Therapy Prolongs Survival of Oral Cancer-Bearing Mice and Inhibits Epithelial-Mesenchymal Transition. Molecules 2017, 22, 629. [CrossRef] [PubMed]

53. Yamamoto, K.; Shichiri, H.; Uda, A.; Yamashita, K.; Nishioka, T.; Kume, M.; Makimoto, H.; Nakagawa, T.; Hirano, T.; Hirai, M. Apoptotic Effects of the Extracts of Cordyceps militaris via Erk Phosphorylation in a Renal Cell Carcinoma Cell Line. Phytother. Res. 2015, 29, 707-713. [CrossRef] [PubMed]

54. Aramwit, P.; Bang, N.; Ratanavaraporn, J.; Nakpheng, T.; Srichana, T. An Anti-Cancer Cordycepin Produced by Cordyceps militaris Growing on the Dead Larva of Bombyx mori Silkworm. J. Agric. Sci. 2014, 6, 41-53. [CrossRef]

55. Glosse, P.; Foller, M. AMP-Activated Protein Kinase (AMPK)-Dependent Regulation of Renal Transport. Int. J. Mol. Sci. 2018, 19, 3481. [CrossRef] [PubMed]

56. Niida, A.; Hiroko, T.; Kasai, M.; Furukawa, Y.; Nakamura, Y.; Suzuki, Y.; Sugano, S.; Akiyama, T. DKK1, a negative regulator of Wnt signaling, is a target of the beta-catenin/TCF pathway. Oncogene 2004, 23, 8520-8526. [CrossRef]

57. Lee, H.J.; Burger, P.; Vogel, M.; Friese, K.; Bruning, A. The nucleoside antagonist cordycepin causes DNA double strand breaks in breast cancer cells. Investig. New Drugs 2012, 30, 1917-1925. [CrossRef]

58. Chen, L.S.; Stellrecht, C.M.; Gandhi, V. RNA-directed agent, cordycepin, induces cell death in multiple myeloma cells. Br. J. Haematol. 2008, 140, 682-691. [CrossRef]

59. Pan, B.S.; Wang, Y.K.; Lai, M.S.; Mu, Y.F.; Huang, B.M. Cordycepin induced MA-10 mouse Leydig tumor cell apoptosis by regulating p38 MAPKs and PI3K/AKT signaling pathways. Sci Rep. 2015, 5, 13372. [CrossRef]

60. Chen, Y.; Yang, S.H.; Hueng, D.Y.; Syu, J.P.; Liao, C.C.; Wu, Y.C. Cordycepin induces apoptosis of C6 glioma cells through the adenosine 2A receptor-p53-caspase-7-PARP pathway. Chem. Biol. Interact. 2014, 216, 17-25. [CrossRef]

61. Kadomatsu, M.; Nakajima, S.; Kato, H.; Gu, L.; Chi, Y.; Yao, J.; Kitamura, M. Cordycepin as a sensitizer to tumour necrosis factor (TNF)- $\alpha$-induced apoptosis through eukaryotic translation initiation factor $2 \alpha$ (eIF2 $\alpha$ )- and mammalian target of rapamycin complex 1 (mTORC1)-mediated inhibition of nuclear factor (NF)-кB. Clin. Exp. Immunol. 2012, 168, 325-332. [CrossRef]

62. Kitamura, M.; Kato, H.; Saito, Y.; Nakajima, S.; Takahashi, S.; Johno, H.; Gu, L.; Katoh, R. Aberrant, differential and bidirectional regulation of the unfolded protein response towards cell survival by $3^{\prime}$-deoxyadenosine. Cell Death Differ. 2011, 18, 1876-1888. [CrossRef] [PubMed]

63. Goldsmith, Z.G.; Dhanasekaran, D.N. G protein regulation of MAPK networks. Oncogene 2007, 26, 3122-3142. [CrossRef] [PubMed] 
64. Pao, H.Y.; Pan, B.S.; Leu, S.F.; Huang, B.M. Cordycepin stimulated steroidogenesis in MA-10 mouse Leydig tumor cells through the protein kinase C Pathway. J. Agric. Food Chem. 2012, 60, 4905-4913. [CrossRef] [PubMed]

65. Lu, M.Y.; Chen, C.C.; Lee, L.Y.; Lin, T.W.; Kuo, C.F. N(6)-(2-Hydroxyethyl)adenosine in the Medicinal Mushroom Cordyceps cicadae Attenuates Lipopolysaccharide-Stimulated Pro-inflammatory Responses by Suppressing TLR4-Mediated NF-кB Signaling Pathways. J. Nat. Prod. 2015, 78, 2452-2460. [CrossRef] [PubMed]

66. Ying, X.; Peng, L.; Chen, H.; Shen, Y.; Yu, K.; Cheng, S. Cordycepin prevented IL- $\beta$-induced expression of inflammatory mediators in human osteoarthritis chondrocytes. Int. Orthop. 2014, 38, 1519-1526. [CrossRef] [PubMed]

67. Yang, X.; Li, Y.; He, Y.; Li, T.; Wang, W.; Zhang, J.; Wei, J.; Deng, Y.; Lin, R. Cordycepin alleviates airway hyperreactivity in a murine model of asthma by attenuating the inflammatory process. Int. Immunopharmacol. 2015, 26, 401-408. [CrossRef] [PubMed]

68. Yuan, J.; Wang, A.; He, Y.; Si, Z.; Xu, S.; Zhang, S.; Wang, K.; Wang, D.; Liu, Y. Cordycepin attenuates traumatic brain injury-induced impairments of blood-brain barrier integrity in rats. Brain Res. Bull. 2016, 127, 171-176. [CrossRef]

69. Yoou, M.S.; Yoon, K.W.; Choi, Y.; Kim, H.M.; Jeong, H.J. Cordycepin diminishes thymic stromal lymphopoietin-induced interleukin-13 production. Eur J. Pharm. 2017, 802, 1-6. [CrossRef]

70. Kan, H.; Wang, Y.; Wang, D.; Sun, H.; Zhou, S.; Wang, H.; Guan, J.; Li, M. Cordycepin rescues lidocaine-induced neurotoxicity in dorsal root ganglion by interacting with inflammatory signaling pathway MMP3. Eur J. Pharm. 2018, 827, 88-93. [CrossRef]

71. Yu, H.M.; Wang, B.S.; Huang, S.C.; Duh, P.D. Comparison of protective effects between cultured Cordyceps militaris and natural Cordyceps sinensis against oxidative damage. J. Agric. Food Chem. 2006, 54, 3132-3138. [CrossRef]

72. Jeong, M.H.; Park, Y.S.; Jeong, D.H.; Lee, C.G.; Kim, J.S.; Oh, S.J.; Jeong, S.K.; Yang, K.; Jo, W.S. In vitro evaluation of Cordyceps militaris as a potential radioprotective agent. Int. J. Mol. Med. 2014, 34, 1349-1357. [CrossRef] [PubMed]

73. Xiao, L.; Ge, Y.; Sun, L.; Xu, X.; Xie, P.; Zhan, M.; Wang, M.; Dong, Z.; Li, J.; Duan, S.; et al. Cordycepin inhibits albumin-induced epithelial-mesenchymal transition of renal tubular epithelial cells by reducing reactive oxygen species production. Free Radic Res. 2012, 46, 174-183. [CrossRef] [PubMed]

74. Olatunji, O.J.; Feng, Y.; Olatunji, O.O.; Tang, J.; Ouyang, Z.; Su, Z. Cordycepin protects PC12 cells against 6-hydroxydopamine induced neurotoxicity via its antioxidant properties. Biomed. Pharm. 2016, 81, 7-14. [CrossRef] [PubMed]

75. Ramesh, T.; Yoo, S.K.; Kim, S.W.; Hwang, S.Y.; Sohn, S.H.; Kim, I.W.; Kim, S.K. Cordycepin (3'-deoxyadenosine) attenuates age-related oxidative stress and ameliorates antioxidant capacity in rats. Exp. Gerontol. 2012, 47, 979-987. [CrossRef] [PubMed]

76. Rottman, F.; Guarino, A.J. The inhibition of purine biosynthesis De novo in Bacillus subtilis by cordycepin. Biochim. Et Biophys. Acta 1964, 80, 640-647. [CrossRef]

77. Philipson, L.; Wall, R.; Glickman, G.; Darnell, J.E. Addition of polyadenylate sequences to virus-specific RNA during adenovirus replication. Proc. Natl. Acad. Sci. USA 1971, 68, 2806-2809. [CrossRef]

78. Aspegren, A.; Bridge, E. Release of snRNP and RNA from transcription sites in adenovirus-infected cells. Exp. Cell Res. 2002, 276, 273-283. [CrossRef]

79. Wu, A.M.; Ting, R.C.; Paran, M.; Gallo, R.C. Cordycepin inhibits induction of murine leukovirus production by 5-iodo-2'-deoxyuridine. Proc. Natl. Acad. Sci. USA 1972, 69, 3820-3824. [CrossRef]

80. Richardson, L.S.; Ting, R.C.; Gallo, R.C.; Wu, A.M. Effect of cordycepin on the replication of type-c RNA tumor viruses. Int. J. Cancer 1975, 15, 451-456. [CrossRef]

81. Weiss, S.R.; Bratt, M.A. Effect of cordycepin (3'-deoxyadenosine) on virus-specific RNA species synthesized in Newcastle disease virus-infected cells. J. Virol. 1975, 16, 1575-1583.

82. Nair, C.N.; Panicali, D.L. Polyadenylate sequences of human rhinovirus and poliovirus RNA and cordycepin sensitivity of virus replication. J. Virol. 1976, 20, 170-176. [PubMed]

83. Leinwand, L.; Ruddle, F.H. Stimulation of in vitro translation of messenger RNA by actinomycin D and cordycepin. Science 1977, 197, 381-383. [CrossRef] [PubMed]

84. Person, A.; Ben-Hamida, F.; Beaud, G. Inhibition of 40S-Met-tRNAfMet ribosomal initiation complex formation by vaccinia virus. Nature 1980, 287, 355-357. [CrossRef] [PubMed] 
85. Luo, G.; Hamatake, R.K.; Mathis, D.M.; Racela, J.; Rigat, K.L.; Lemm, J.; Colonno, R.J. De novo initiation of RNA synthesis by the RNA-dependent RNA polymerase (NS5B) of hepatitis C virus. J. Virol. 2000, 74, 851-863. [CrossRef] [PubMed]

86. Ahn, Y.J.; Park, S.J.; Lee, S.G.; Shin, S.C.; Choi, D.H. Cordycepin: Selective growth inhibitor derived from liquid culture of Cordyceps militaris against Clostridium spp. J. Agric. Food Chem. 2000, 48, 2744-2748. [CrossRef] [PubMed]

87. Sugar, A.M.; McCaffrey, R.P. Antifungal activity of $3^{\prime}$-deoxyadenosine (cordycepin). Antimicrob. Agents Chemother. 1998, 42, 1424-1427. [CrossRef] [PubMed]

88. Barouch, D.H.; Tomaka, F.L.; Wegmann, F.; Stieh, D.J.; Alter, G.; Robb, M.L.; Michael, N.L.; Peter, L.; Nkolola, J.P.; Borducchi, E.N.; et al. Evaluation of a mosaic HIV-1 vaccine in a multicentre, randomised, double-blind, placebo-controlled, phase 1/2a clinical trial (APPROACH) and in rhesus monkeys (NHP 13-19). Lancet 2018, 392, 232-243. [CrossRef]

89. Kim, J.R.; Yeon, S.H.; Kim, H.S.; Ahn, Y.J. Larvicidal activity against Plutella xylostella of cordycepin from the fruiting body of Cordyceps militaris. Pest. Manag. Sci. 2002, 58, 713-717. [CrossRef]

90. Vodnala, S.K.; Ferella, M.; Lunden-Miguel, H.; Betha, E.; van Reet, N.; Amin, D.N.; Oberg, B.; Andersson, B.; Kristensson, K.; Wigzell, H.; et al. Preclinical assessment of the treatment of second-stage African trypanosomiasis with cordycepin and deoxycoformycin. PLoS Negl. Trop. Dis. 2009, 3, e495. [CrossRef]

91. Dalla Rosa, L.; da Silva, A.S.; Gressler, L.T.; Oliveira, C.B.; Dambros, M.G.; Miletti, L.C.; Franca, R.T.; Lopes, S.T.; Samara, Y.N.; da Veiga, M.L.; et al. Cordycepin(3'-deoxyadenosine) pentostatin (deoxycoformycin) combination treatment of mice experimentally infected with Trypanosoma evansi. Parasitology 2013, 140, 663-671. [CrossRef]

92. Dalla Rosa, L.; Da Silva, A.S.; Oliveira, C.B.; Gressler, L.T.; Arnold, C.B.; Baldissera, M.D.; Sagrillo, M.; Sangoi, M.; Moresco, R.; Mendes, R.E.; et al. Dose finding of 3'deoxyadenosine and deoxycoformycin for the treatment of Trypanosoma evansi infection: An effective and nontoxic dose. Microb. Pathog. 2015, 85, 21-28. [CrossRef] [PubMed]

93. Park, D.C.; Yeo, S.G. Aging. Korean J. Audiol. 2013, 17, 39-44. [CrossRef] [PubMed]

94. He, Y.T.; Zhang, X.L.; Xie, Y.M.; Xu, Y.X.; Li, J.R. Extraction and Antioxidant Property In Vitro of Cordycepin in Artificially Cultivated Cordyceps Militaris. Adv. Mater. Res. 2013, 750-752, 1593-1596. [CrossRef]

95. Lee, Y.R.; Noh, E.M.; Jeong, E.Y.; Yun, S.K.; Jeong, Y.J.; Kim, J.H.; Kwon, K.B.; Kim, B.S.; Lee, S.H.; Park, C.S.; et al. Cordycepin inhibits UVB-induced matrix metalloproteinase expression by suppressing the NF-kappaB pathway in human dermal fibroblasts. Exp. Mol. Med. 2009, 41, 548-854. [CrossRef] [PubMed]

96. Chen, M.; Cheung, F.W.; Chan, M.H.; Hui, P.K.; Ip, S.P.; Ling, Y.H.; Che, C.T.; Liu, W.K. Protective roles of Cordyceps on lung fibrosis in cellular and rat models. J. Ethnopharmacol. 2012, 143, 448-454. [CrossRef] [PubMed]

97. Gu, L.; Johno, H.; Nakajima, S.; Kato, H.; Takahashi, S.; Katoh, R.; Kitamura, M. Blockade of Smad signaling by 3'-deoxyadenosine: A mechanism for its anti-fibrotic potential. Lab. Investig. 2013, 93, 450-461. [CrossRef]

98. Park, E.S.; Kang, D.H.; Yang, M.K.; Kang, J.C.; Jang, Y.C.; Park, J.S.; Kim, S.K.; Shin, H.S. Cordycepin, 3'-Deoxyadenosine, Prevents Rat Hearts from Ischemia/Reperfusion Injury Via Activation of Akt/GSK-3 beta/p70S6K Signaling Pathway and HO-1 Expression. Cardiovasc. Toxicol. 2014, 14, 1-9. [CrossRef]

99. Cheng, Z.; He, W.; Zhou, X.; Lv, Q.; Xu, X.; Yang, S.; Zhao, C.; Guo, L. Cordycepin protects against cerebral ischemia/reperfusion injury in vivo and in vitro. Eur J. Pharm. 2011, 664, 20-28. [CrossRef]

100. Jung, S.M.; Park, S.S.; Kim, W.J.; Moon, S.K. Ras/ERK1 pathway regulation of p27KIP1-mediated G1-phase cell-cycle arrest in cordycepin-induced inhibition of the proliferation of vascular smooth muscle cells. Eur J. Pharm. 2012, 681, 15-22. [CrossRef]

101. Yao, L.H.; Yu, H.M.; Xiong, Q.P.; Sun, W.; Xu, Y.L.; Meng, W.; Li, Y.P.; Liu, X.P.; Yuan, C.H. Cordycepin Decreases Compound Action Potential Conduction of Frog Sciatic Nerve In Vitro Involving Ca(2+)-Dependent Mechanisms. Neural Plast. 2015, 2015, 927817. [CrossRef]

102. Ferrari, L.F.; Araldi, D.; Levine, J.D. Distinct terminal and cell body mechanisms in the nociceptor mediate hyperalgesic priming. J. Neurosci 2015, 35, 6107-6116. [CrossRef] [PubMed]

103. Ferrari, L.F.; Bogen, O.; Chu, C.; Levine, J.D. Peripheral administration of translation inhibitors reverses increased hyperalgesia in a model of chronic pain in the rat. J. Pain 2013, 14, 731-738. [CrossRef] [PubMed] 
104. Yao, L.H.; Meng, W.; Song, R.F.; Xiong, Q.P.; Sun, W.; Luo, Z.Q.; Yan, W.W.; Li, Y.P.; Li, X.P.; Li, H.H.; et al. Modulation effects of cordycepin on the skeletal muscle contraction of toad gastrocnemius muscle. Eur J. Pharm. 2014, 726, 9-15. [CrossRef]

105. Takahashi, S.; Tamai, M.; Nakajima, S.; Kato, H.; Johno, H.; Nakamura, T.; Kitamura, M. Blockade of adipocyte differentiation by cordycepin. Br. J. Pharm. 2012, 167, 561-575. [CrossRef]

106. Cha, J.Y.; Ahn, H.Y.; Cho, Y.S.; Je, J.Y. Protective effect of cordycepin-enriched Cordyceps militaris on alcoholic hepatotoxicity in Sprague-Dawley rats. Food Chem. Toxicol. 2013, 60, 52-57. [CrossRef]

107. Guo, P.; Kai, Q.; Gao, J.; Lian, Z.Q.; Wu, C.M.; Wu, C.A.; Zhu, H.B. Cordycepin prevents hyperlipidemia in hamsters fed a high-fat diet via activation of AMP-activated protein kinase. J. Pharm. Sci. 2010, 113, 395-403. [CrossRef]

108. Wu, C.; Guo, Y.; Su, Y.; Zhang, X.; Luan, H.; Zhang, X.; Zhu, H.; He, H.; Wang, X.; Sun, G.; et al. Cordycepin activates AMP-activated protein kinase (AMPK) via interaction with the gamma1 subunit. J. Cell Mol. Med. 2014, 18, 293-304. [CrossRef] [PubMed]

109. Li, B.; Hou, Y.; Zhu, M.; Bao, H.; Nie, J.; Zhang, G.Y.; Shan, L.; Yao, Y.; Du, K.; Yang, H.; et al. 3'-Deoxyadenosine (Cordycepin) Produces a Rapid and Robust Antidepressant Effect via Enhancing Prefrontal AMPA Receptor Signaling Pathway. Int. J. Neuropsychopharmacol. 2016, 19, pyv112. [CrossRef]

110. Dou, C.; Cao, Z.; Ding, N.; Hou, T.; Luo, F.; Kang, F.; Yang, X.; Jiang, H.; Xie, Z.; Hu, M.; et al. Cordycepin Prevents Bone Loss through Inhibiting Osteoclastogenesis by Scavenging ROS Generation. Nutrients 2016, 8 , 231. [CrossRef] [PubMed]

111. Chen, Y.X.; Zhu, D.Y.; Xu, Z.L.; Yin, J.H.; Yu, X.W.; Mei, J.; Gao, Y.S.; Zhang, C.Q. The Protective Effect of Cordycepin On Alcohol-Induced Osteonecrosis of the Femoral Head. Cell Physiol. Biochem. 2017, 42, 2391-2403. [CrossRef]

112. Cao, Z.; Dou, C.; Li, J.; Tang, X.; Xiang, J.; Zhao, C.; Zhu, L.; Bai, Y.; Xiang, Q.; Dong, S. Cordycepin inhibits chondrocyte hypertrophy of mesenchymal stem cells through PI3K/Bapx1 and Notch signaling pathway. Bmb Rep. 2016, 49, 548-553. [CrossRef] [PubMed]

113. Manszewski, T.; Szpotkowski, K.; Jaskolski, M. Crystallographic and SAXS studies of S-adenosyl1-homocysteine hydrolase from Bradyrhizobium elkanii. IUCrJ 2017, 4, 271-282. [CrossRef] [PubMed]

114. Yang, Q.; Nausch, L.W.; Martin, G.; Keller, W.; Doublie, S. Crystal structure of human poly(A) polymerase gamma reveals a conserved catalytic core for canonical poly(A) polymerases. J. Mol. Biol. 2014, 426, 43-50. [CrossRef] [PubMed]

115. Lui, J.C.; Wong, J.W.; Suen, Y.K.; Kwok, T.T.; Fung, K.P.; Kong, S.K. Cordycepin induced eryptosis in mouse erythrocytes through a $\mathrm{Ca}^{2+}$-dependent pathway without caspase-3 activation. Arch. Toxicol. 2007, 81, 859-865. [CrossRef] [PubMed]

116. Roy, S.; Beauchemin, M.; Dagenais-Bellefeuille, S.; Letourneau, L.; Cappadocia, M.; Morse, D. The Lingulodinium circadian system lacks rhythmic changes in transcript abundance. BMC Biol. 2014, 12, 107. [CrossRef] [PubMed]

117. Nguyen, C.C.; Nakaminami, K.; Matsui, A.; Kobayashi, S.; Kurihara, Y.; Toyooka, K.; Tanaka, M.; Seki, M. Oligouridylate Binding Protein $1 \mathrm{~b}$ Plays an Integral Role in Plant Heat Stress Tolerance. Front. Plant. Sci. 2016, 7, 853. [CrossRef] [PubMed]

118. Koc, Y.; Urbano, A.G.; Sweeney, E.B.; McCaffrey, R. Induction of apoptosis by cordycepin in ADA-inhibited TdT-positive leukemia cells. Leukemia 1996, 10, 1019-1024. [PubMed]

119. Chou, S.M.; Lai, W.J.; Hong, T.W.; Lai, J.Y.; Tsai, S.H.; Chen, Y.H.; Yu, S.H.; Kao, C.H.; Chu, R.; Ding, S.T.; et al. Synergistic property of cordycepin in cultivated Cordyceps militaris-mediated apoptosis in human leukemia cells. Phytomedicine 2014, 21, 1516-1524. [CrossRef] [PubMed]

120. Chen, X.; Wang, Y.; Liu, J.; Xu, P.; Zhang, X.M.; Tian, Y.Y.; Xue, Y.M.; Gao, X.Y.; Liu, Y.; Wang, J.H. Synergistic effect of HMGB1 knockdown and cordycepin in the K562 human chronic myeloid leukemia cell line. Mol. Med. Rep. 2015, 12, 4462-4468. [CrossRef] [PubMed]

121. Kim, H.; Naura, A.S.; Errami, Y.; Ju, J.; Boulares, A.H. Cordycepin blocks lung injury-associated inflammation and promotes BRCA1-deficient breast cancer cell killing by effectively inhibiting PARP. Mol. Med. 2011, 17, 893-900. [CrossRef]

122. Lee, H.H.; Park, C.; Jeong, J.W.; Kim, M.J.; Seo, M.J.; Kang, B.W.; Park, J.U.; Kim, G.Y.; Choi, B.T.; Choi, Y.H.; et al. Apoptosis induction of human prostate carcinoma cells by cordycepin through reactive oxygen species mediated mitochondrial death pathway. Int. J. Oncol. 2013, 42, 1036-1044. [CrossRef] [PubMed] 
123. Lee, H.H.; Jeong, J.W.; Lee, J.H.; Kim, G.Y.; Cheong, J.; Jeong, Y.K.; Yoo, Y.H.; Choi, Y.H. Cordycepin increases sensitivity of Hep3B human hepatocellular carcinoma cells to TRAIL-mediated apoptosis by inactivating the JNK signaling pathway. Oncol. Rep. 2013, 30, 1257-1264. [CrossRef] [PubMed]

124. Chen, Y.Y.; Liu, F.C.; Wu, T.S.; Sheu, M.J. Antrodia cinnamomea Inhibits Migration in Human Hepatocellular Carcinoma Cells: The Role of ERp57 and PGK-1. Am. J. Chin. Med. 2015, 43, 1671-1696. [CrossRef] [PubMed]

125. Wang, X.A.; Xiang, S.S.; Li, H.F.; Wu, X.S.; Li, M.L.; Shu, Y.J.; Zhang, F.; Cao, Y.; Ye, Y.Y.; Bao, R.F.; et al. Cordycepin induces $S$ phase arrest and apoptosis in human gallbladder cancer cells. Molecules 2014, 19, 11350-11365. [CrossRef] [PubMed]

126. Qing, R.; Huang, Z.; Tang, Y.; Xiang, Q.; Yang, F. Cordycepin negatively modulates lipopolysaccharide-induced cytokine production by up-regulation of heme oxygenase-1. Int. Immunopharmacol. 2017, 47, 20-27. [CrossRef]

127. Li, Y.; Li, K.; Mao, L.; Han, X.; Zhang, K.; Zhao, C.; Zhao, J. Cordycepin inhibits LPS-induced inflammatory and matrix degradation in the intervertebral disc. PeerJ 2016, 4, e1992. [CrossRef] [PubMed]

128. Fei, X.; Zhang, X.; Zhang, G.Q.; Bao, W.P.; Zhang, Y.Y.; Zhang, M.; Zhou, X. Cordycepin inhibits airway remodeling in a rat model of chronic asthma. Biomed. Pharm. 2017, 88, 335-341. [CrossRef]

129. Lee, J.Y.; Choi, H.Y.; Baik, H.H.; Ju, B.G.; Kim, W.K.; Yune, T.Y. Cordycepin-enriched WIB-801C from Cordyceps militaris improves functional recovery by attenuating blood-spinal cord barrier disruption after spinal cord injury. J. Ethnopharmacol. 2017, 203, 90-100. [CrossRef] [PubMed]

130. Lei, J.; Wei, Y.; Song, P.; Li, Y.; Zhang, T.; Feng, Q.; Xu, G. Cordycepin inhibits LPS-induced acute lung injury by inhibiting inflammation and oxidative stress. Eur J. Pharm. 2018, 818, 110-114. [CrossRef] [PubMed]

131. Araldi, D.; Ferrari, L.F.; Levine, J.D. Gi-protein-coupled 5-HT1B/D receptor agonist sumatriptan induces type I hyperalgesic priming. Pain 2016, 157, 1773-1782. [CrossRef]

132. Liu, Z.B.; Liu, C.; Zeng, B.; Huang, L.P.; Yao, L.H. Modulation Effects of Cordycepin on Voltage-Gated Sodium Channels in Rat Hippocampal CA1 Pyramidal Neurons in the Presence/Absence of Oxygen. Neural. Plast. 2017, 2017, 2459053. [CrossRef]

133. Yong, T.; Chen, S.; Xie, Y.; Chen, D.; Su, J.; Shuai, O.; Jiao, C.; Zuo, D. Cordycepin, a Characteristic Bioactive Constituent in Cordyceps militaris,Ameliorates Hyperuricemia through URAT1 in Hyperuricemic Mice. Front. Microbiol. 2018, 9, 58. [CrossRef] [PubMed]

134. Aramwit, P.; Porasuphatana, S.; Srichana, T.; Nakpheng, T. Toxicity evaluation of cordycepin and its delivery system for sustained in vitro anti-lung cancer activity. Nanoscale Res. Lett. 2015, 10, 152. [CrossRef]

135. Tsai, Y.J.; Lin, L.C.; Tsai, T.H. Pharmacokinetics of adenosine and cordycepin, a bioactive constituent of Cordyceps sinensis in rat. J. Agric. Food Chem. 2010, 58, 4638-4643. [CrossRef]

136. Lee, J.B.; Adrower, C.; Qin, C.; Fischer, P.M.; de Moor, C.H.; Gershkovich, P. Development of Cordycepin Formulations for Preclinical and Clinical Studies. Aaps Pharmscitech. 2017, 18, 3219-3226. [CrossRef] [PubMed]

137. OncoVista, I.; AAIPharma, I. Study of Cordycepin Plus Pentostatin in Patients With Refractory TdT-Positive Leukemia. Available online: https://clinicaltrials.gov/show/NCT00709215 (accessed on 9 January 2009).

138. De Clercq, E. Curious (Old and New) Antiviral Nucleoside Analogues with Intriguing Therapeutic Potential. Curr. Med. Chem 2015, 22, 3866-3880. [CrossRef]

139. Wei, H.P.; Ye, X.L.; Chen, Z.; Zhong, Y.J.; Li, P.M.; Pu, S.C.; Li, X.G. Synthesis and pharmacokinetic evaluation of novel N-acyl-cordycepin derivatives with a normal alkyl chain. Eur. J. Med. Chem. 2009, 44, 665-669. [CrossRef]

140. Vodnala, S.K.; Lundback, T.; Yeheskieli, E.; Sjoberg, B.; Gustavsson, A.L.; Svensson, R.; Olivera, G.C.; Eze, A.A.; de Koning, H.P.; Hammarstrom, L.G.; et al. Structure-activity relationships of synthetic cordycepin analogues as experimental therapeutics for African trypanosomiasis. J. Med. Chem. 2013, 56, 9861-9873. [CrossRef] [PubMed]

141. Chen, Z.G.; Zhang, D.N.; Cao, L.; Han, Y.B. Highly efficient and regioselective acylation of pharmacologically interesting cordycepin catalyzed by lipase in the eco-friendly solvent 2-methyltetrahydrofuran. Bioresour. Technol. 2013, 133, 82-86. [CrossRef]

142. Yang, Q.Z.; Yang, J.; Zhang, C.K. Synthesis and properties of cordycepin intercalates of Mg-Al-nitrate layered double hydroxides. Int J. Pharm. 2006, 326, 148-152. [CrossRef]

143. Bi, Y.E.; Zhou, Y.; Wang, M.; Li, L.; Lee, R.J.; Xie, J.; Teng, L. Targeted Delivery of Cordycepin to Liver Cancer Cells Using Transferrin-conjugated Liposomes. Anticancer Res. 2017, 37, 5207-5214. [PubMed] 
144. Federici, C.; Petrucci, F.; Caimi, S.; Cesolini, A.; Logozzi, M.; Borghi, M.; D’Ilio, S.; Lugini, L.; Violante, N.; Azzarito, T.; et al. Exosome release and low $\mathrm{pH}$ belong to a framework of resistance of human melanoma cells to cisplatin. PLoS ONE 2014, 9, e88193. [CrossRef] [PubMed]

145. Chapuy, B.; Koch, R.; Radunski, U.; Corsham, S.; Cheong, N.; Inagaki, N.; Ban, N.; Wenzel, D.; Reinhardt, D.; Zapf, A.; et al. Intracellular ABC transporter A3 confers multidrug resistance in leukemia cells by lysosomal drug sequestration. Leukemia 2008, 22, 1576-1586. [CrossRef] [PubMed]

146. Shin, J.S.; Chung, S.H.; Lee, W.S.; Lee, J.Y.; Kim, J.L.; Lee, K.T. Immunostimulatory effects of cordycepin-enriched WIB-801CE from Cordyceps militaris in splenocytes and cyclophosphamide-induced immunosuppressed mice. Phytother. Res. 2018, 32, 132-139. [CrossRef]

147. Taylor, J.W. One Fungus = One Name: DNA and fungal nomenclature twenty years after PCR. Ima Fungus 2011, 2, 113-120. [CrossRef]

148. Berkeley, M.J. On some entomogenous Sphaeriae. Lond. J. Bot. 1843, 2, 205-211. [CrossRef]

149. Saccardo, P.A. Enumeratio pyrenomycetum hypocreaceorum huscusque congnitorum systemate xarpologico dispositorum. Michelia 1878, 1, 277-325.

150. Hu, T.; Jiang, C.; Huang, Q.; Sun, F. A comb-like branched $\beta$-d-glucan produced by a Cordyceps sinensis fungus and its protective effect against cyclophosphamide-induced immunosuppression in mice. Carbohydr. Polym. 2016, 142, 259-267. [CrossRef] [PubMed]

151. Sung, G.H.; Hywel-Jones, N.L.; Sung, J.M.; Luangsa-Ard, J.J.; Shrestha, B.; Spatafora, J.W. Phylogenetic classification of Cordyceps and the clavicipitaceous fungi. Stud. Mycol. 2007, 57, 5-59. [CrossRef]

152. Wei, J.C.; Wei, X.L.; Zheng, W.F.; Guo, W.; Liu, R. Species identification and component detection of Ophiocordyceps sinensis cultivated by modern industry. Mycosystema 2016, 35, 404-410.

153. Jiangm, Y.; Yao, Y.J. Names related to Cordyceps sinensis anamorph. Mycotaxon 2002, 84, 245-254.

154. Liu, Z.-Y.; Yao, Y.-J.; Qi Liang, Z.; Liu, A.-Y.; Pegler, D.N.; Chase, M.W. Molecular evidence for the anamorph-teleomorph connection in Cordyceps sinensis. Mycol. Res. 2001, 105, 827-832. [CrossRef]

155. Jiapeng, T.; Yiting, L.; Li, Z. Optimization of fermentation conditions and purification of cordycepin from Cordyceps militaris. Prep. Biochem. Biotechnol. 2014, 44, 90-106. [CrossRef] [PubMed]

156. Cohen, N.; Cohen, J.; Asatiani, M.D.; Varshney, V.K.; Yu, H.T.; Yang, Y.C.; Li, Y.H.; Mau, J.L.; Wasser, S.P. Chemical composition and nutritional and medicinal value of fruit bodies and submerged cultured mycelia of culinary-medicinal higher Basidiomycetes mushrooms. Int J. Med. Mushrooms 2014, 16, 273-291. [CrossRef] [PubMed]

157. Xiang, L.; Li, Y.; Zhu, Y.; Luo, H.; Li, C.; Xu, X.; Sun, C.; Song, J.; Shi, L.; He, L.; et al. Transcriptome analysis of the Ophiocordyceps sinensis fruiting body reveals putative genes involved in fruiting body development and cordycepin biosynthesis. Genomics 2014, 103, 154-159. [CrossRef]

158. Jin, J.; Kang, W.; Zhong, C.; Qin, Y.; Zhou, R.; Liu, H.; Xie, J.; Chen, L.; Qin, Y.; Zhang, S. The pharmacological properties of Ophiocordyceps xuefengensis revealed by transcriptome analysis. J. Ethnopharmacol. 2018, 219, 195-201. [CrossRef]

159. Hu, H.; Xiao, L.; Zheng, B.; Wei, X.; Ellis, A.; Liu, Y.M. Identification of chemical markers in Cordyceps sinensis by HPLC-MS/MS. Anal. Bioanal. Chem. 2015, 407, 8059-8066. [CrossRef]

160. Jin, J.; Zhong, C.; Qin, Y.; Cai, Y.; Zhen, L.; Shen, B.; Chen, L.; Wan, D.; Qin, Y.; Zhang, S. A new cordycepin-producing caterpillar fungus Ophiocordyceps xuefengensis with artificial infection to the host, cultivation of mycelia and stromata. FEMS Microbiol. Lett. 2017, 364, fnx181. [CrossRef]

161. Masuda, M.; Urabe, E.; Honda, H.; Sakurai, A.; Sakakibara, M. Enhanced production of cordycepin by surface culture using the medicinal mushroom Cordyceps militaris. Enzym. Microb. Technol. 2007, 40, 1199-1205. [CrossRef]

162. Das, S.K.; Masuda, M.; Sakurai, A.; Sakakibara, M. Effects of additives on Cordycepin production using a Cordyceps militaris mutant induced by ion beam irradiation. Afr. J. Biotechnol. 2009, 8, 3041-3047.

163. Yang, F.Q.; Ge, L.; Yong, J.W.; Tan, S.N.; Li, S.P. Determination of nucleosides and nucleobases in different species of Cordyceps by capillary electrophoresis-mass spectrometry. J. Pharm. Biomed. Anal. 2009, 50, 307-314. [CrossRef] [PubMed]

164. Masuda, M.; Das, S.K.; Fujihara, S.; Hatashita, M.; Sakurai, A. Production of cordycepin by a repeated batch culture of a Cordyceps militaris mutant obtained by proton beam irradiation. J. Biosci. Bioeng. 2011, 111, 55-60. [CrossRef] [PubMed] 
165. Wang, Y.; Guo, Y.; Zhang, L.; Wu, J. Characterizations of a new Cordyceps cicadae isolate and production of adenosine and cordycepin. Braz J. Microbiol. 2012, 43, 449-455. [CrossRef] [PubMed]

166. Wang, H.J.; Pan, M.C.; Chang, C.K.; Chang, S.W.; Hsieh, C.W. Optimization of ultrasonic-assisted extraction of cordycepin from Cordyceps militaris using orthogonal experimental design. Molecules 2014, 19, 20808-20820. [CrossRef] [PubMed]

167. Hung, Y.P.; Wang, J.J.; Wei, B.L.; Lee, C.L. Effect of the salts of deep ocean water on the production of cordycepin and adenosine of Cordyceps militaris-fermented product. Amb Express 2015, 5, 140. [CrossRef] [PubMed]

168. Sari, N.; Suparmin, A.; Kato, T.; Park, E.Y. Improved cordycepin production in a liquid surface culture of Cordyceps militaris isolated from wild strain. Biotechnol. Bioprocess. Eng. 2016, 21, 595-600. [CrossRef]

169. Kang, N.; Lee, H.H.; Park, I.; Seo, Y.S. Development of High Cordycepin-Producing Cordyceps militaris Strains. Mycobiology 2017, 45, 31-38. [CrossRef] [PubMed]

170. Suparmin, A.; Kato, T.; Dohra, H.; Park, E.Y. Insight into cordycepin biosynthesis of Cordyceps militaris: Comparison between a liquid surface culture and a submerged culture through transcriptomic analysis. PLoS ONE 2017, 12, e0187052. [CrossRef]

171. Wang, Y.; Zhang, G.; Zhao, X.; Ling, J. Genome shuffling improved the nucleosides production in Cordyceps kyushuensis. J. Biotechnol. 2017, 260, 42-47. [CrossRef]

172. Zhang, J.; Wang, F.; Liu, K.; Liu, Q.; Yang, Y.; Dong, C. Heat and light stresses affect metabolite production in the fruit body of the medicinal mushroom Cordyceps militaris. Appl. Microbiol. Biotechnol. 2018, 102, $4523-4533$.

173. Lin, L.T.; Lai, Y.J.; Wu, S.C.; Hsu, W.H.; Tai, C.J. Optimal conditions for cordycepin production in surface liquid-cultured Cordyceps militaris treated with porcine liver extracts for suppression of oral cancer. J. Food Drug Anal. 2018, 26, 135-144. [CrossRef] [PubMed]

174. Meng, Z.; Wen, T.; Kang, J.; Lei, B.; Hyde, K. Cordyceps pruinosa produces cordycepin and N6-(2-hydroxyethyl)-adenosine in culture. Arch. Biol. Sci. 2014, 66, 1411-1421. [CrossRef]

175. Pang, F.; Wang, L.; Jin, Y.; Guo, L.; Song, L.; Liu, G.; Feng, C. Transcriptome analysis of Paecilomyces hepiali at different growth stages and culture additives to reveal putative genes in cordycepin biosynthesis. Genomics 2018, 110, 162-170. [CrossRef]

176. Xia, E.H.; Yang, D.R.; Jiang, J.J.; Zhang, Q.J.; Liu, Y.; Liu, Y.L.; Zhang, Y.; Zhang, H.B.; Shi, C.; Tong, Y.; et al. The caterpillar fungus, Ophiocordyceps sinensis, genome provides insights into highland adaptation of fungal pathogenicity. Sci. Rep. 2017, 7, 1806. [CrossRef] [PubMed]

177. Yang, T.; Guo, M.; Yang, H.; Guo, S.; Dong, C. The blue-light receptor CmWC-1 mediates fruit body development and secondary metabolism in Cordyceps militaris. Appl. Microbiol. Biotechnol. 2016, 100, 743-755. [CrossRef] [PubMed]

178. Yang, T.; Dong, C. Photo morphogenesis and photo response of the blue-light receptor gene Cmwc-1 in different strains of Cordyceps militaris. Fems Microbiol. Lett. 2014, 352, 190-197. [CrossRef]

179. Wang, F.; Song, X.; Dong, X.; Zhang, J.; Dong, C. DASH-type cryptochromes regulate fruiting body development and secondary metabolism differently than CmWC-1 in the fungus Cordyceps militaris. Appl. Microbiol. Biotechnol. 2017, 101, 4645-4657. [CrossRef] [PubMed]

180. Kredich, N.M.; Guarino, A.J. Studies on the biosynthesis of cordycepin. Biochim. Et Biophys. Acta 1961,47, 529-534. [CrossRef]

181. Chassy, B.M.; Suhadolnik, R.J. Nucleoside antibiotics. IV. Metabolic fate of adenosine and cordycepin by Cordyceps militaris during cordycepin biosynthesis. Biochim. Et Biophys. Acta 1969, 182, 307-315. [CrossRef]

182. Lennon, M.B.; Suhadolnik, R.J. Biosynthesis of $3^{\prime}$-deoxyadenosine by Cordyceps militaris. Mechanism of reduction. Biochim. Et Biophys. Acta 1976, 425, 532-536. [CrossRef]

183. Zheng, P.; Xia, Y.; Xiao, G.; Xiong, C.; Hu, X.; Zhang, S.; Zheng, H.; Huang, Y.; Zhou, Y.; Wang, S.; et al. Genome sequence of the insect pathogenic fungus Cordyceps militaris, a valued traditional Chinese medicine. Genome Biol. 2011, 12, R116. [CrossRef] [PubMed]

184. Fan, D.-d.; Wang, W.; Zhong, J.-J. Enhancement of cordycepin production in submerged cultures of Cordyceps militaris by addition of ferrous sulfate. Biochem. Eng. J. 2012, 60, 30-35. [CrossRef]

185. Zhang, Q.; Liu, Y. The strategies for increasing cordycepin production of Cordyceps militaris by liquid fermentation. Fungal Genom. Biol. 2016, 6, 134. [CrossRef] 
186. Kuo, H.-C.; Huang, I.C.; Chen, T.-Y. Cordyceps s.L. (Ascomycetes) species used as medicinal mushrooms are closely related with higher ability to produce cordycepin. Int. J. Med. Mushrooms 2016, 17, 1077-1085. [CrossRef]

187. Vongsangnak, W.; Raethong, N.; Mujchariyakul, W.; Nguyen, N.N.; Leong, H.W.; Laoteng, K. Genome-scale metabolic network of Cordyceps militaris useful for comparative analysis of entomopathogenic fungi. Gene 2017, 626, 132-139. [CrossRef] [PubMed]

188. Kato, T.; Ahmad, S.; Park, E.Y. Functional Analysis of Ribonucleotide Reductase from Cordyceps militaris Expressed in Escherichia coli. Appl. Biochem. Biotechnol. 2017, 182, 1307-1317. [CrossRef] [PubMed]

189. Wu, P.; Wan, D.; Xu, G.; Wang, G.; Ma, H.; Wang, T.; Gao, Y.; Qi, J.; Chen, X.; Zhu, J.; et al. An unusual protector-prote' ge' strategy for the biosynthesis of purine nucleoside antibiotics. Cell Chem. Biol. 2017, 24, 171-181. [CrossRef]

190. Li, G.; Nakagome, I.; Hirono, S.; Itoh, T.; Fujiwara, R. Inhibition of adenosine deaminase (ADA)-mediated metabolism of cordycepin by natural substances. Pharm. Res. Perspect 2015, 3, e00121. [CrossRef]

191. Yin, Y.; Yu, G.; Chen, Y.; Jiang, S.; Wang, M.; Jin, Y.; Lan, X.; Liang, Y.; Sun, H. Genome-wide transcriptome and proteome analysis on different developmental stages of Cordyceps militaris. PLoS ONE 2012, 7, e51853. [CrossRef]

192. Tudzynski, P.; Heller, J.; Siegmund, U. Reactive oxygen species generation in fungal development and pathogenesis. Curr. Opin. Microbiol. 2012, 15, 653-659. [CrossRef]

193. Li, W.; Zhang, Z.; Li, Q. Research progress of host insect of Cordyceps and its raising technique. World Chin. Med. 2017, 12, 3142-3150.

194. Zhang, Y.; Zhang, S.; Li, Y.; Ma, S.; Wang, C.; Xiang, M.; Liu, X.; An, Z.; Xu, J.; Liu, X. Phylogeography and evolution of a fungal-insect association on the Tibetan Plateau. Mol. Ecol. 2014, 23, 5337-5355. [CrossRef] [PubMed]

195. Chen, Y.; Ding, Y.F.; Yang, L.; Yu, J.H.; Liu, G.M.; Wang, X.M.; Zhang, S.Y.; Yu, D.; Song, L.; Zhang, H.X.; et al. Integrated omics study delineates the dynamics of lipid droplets in Rhodococcus opacus PD630. Nucleic Acids Res. 2014, 42, 1052-1064. [CrossRef] [PubMed]

196. Newman, D.J.; Cragg, G.M. Natural Products as Sources of New Drugs from 1981 to 2014. J. Nat. Prod. 2016, 79, 629-661. [CrossRef] [PubMed]

197. Covington, B.C.; McLean, J.A.; Bachmann, B.O. Comparative mass spectrometry-based metabolomics strategies for the investigation of microbial secondary metabolites. Nat. Prod. Rep. 2017, 34, 6-24. [CrossRef]

198. Gesmundo, N.J.; Sauvagnat, B.; Curran, P.J.; Richards, M.P.; Andrews, C.L.; Dandliker, P.J.; Cernak, T. Nanoscale synthesis and affinity ranking. Nature 2018, 557, 228-232. [CrossRef]

199. Baslan, T.; Hicks, J. Unravelling biology and shifting paradigms in cancer with single-cell sequencing. Nat. Rev. Cancer 2017, 17, 557-569. [CrossRef]

200. Packer, J.; Trapnell, C. Single-Cell Multi-omics: An Engine for New Quantitative Models of Gene Regulation. Trends Genet. 2018, 34, 653-665. [CrossRef]

201. Rosenberg, A.B.; Roco, C.M.; Muscat, R.A.; Kuchina, A.; Sample, P.; Yao, Z.; Graybuck, L.T.; Peeler, D.J.; Mukherjee, S.; Chen, W.; et al. Single-cell profiling of the developing mouse brain and spinal cord with split-pool barcoding. Science 2018, 360, 176-182. [CrossRef]

202. Miller, M.A.; Weissleder, R. Imaging of anticancer drug action in single cells. Nat. Rev. Cancer 2017, 17, 399-414. [CrossRef]

203. Jing, M.; Zhang, P.; Wang, G.; Feng, J.; Mesik, L.; Zeng, J.; Jiang, H.; Wang, S.; Looby, J.C.; Guagliardo, N.A.; et al. A genetically encoded fluorescent acetylcholine indicator for in vitro and in vivo studies. Nat. Biotechnol. 2018, 36, 726-737. [CrossRef] [PubMed]

(C) 2019 by the authors. Licensee MDPI, Basel, Switzerland. This article is an open access article distributed under the terms and conditions of the Creative Commons Attribution (CC BY) license (http://creativecommons.org/licenses/by/4.0/). 